\title{
Measuring the Contribution of Criminal Justice Systems to the Control of Crime and Violence: Lessons from Jamaica and the Dominican Republic
}

Todd Foglesong and Christopher Stone

CID Working Paper No. 144

April 2007

(C) Copyright 2007 Todd Foglesong, Christopher Stone, and the President and Fellows of Harvard College

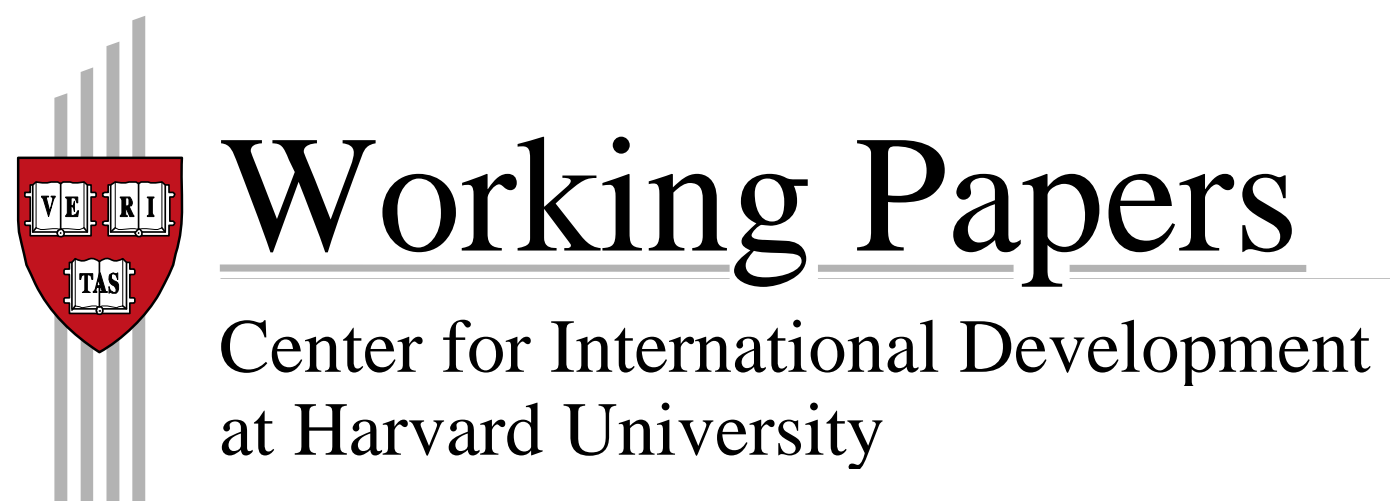




\title{
Measuring the Contribution of Criminal Justice Systems to the Control of Crime and Violence: Lessons from Jamaica and the Dominican Republic
}

\author{
Todd Foglesong and Christopher Stone ${ }^{1}$
}

\begin{abstract}
Governments facing high levels of crime and violence must act through their criminal justice systems to increase safety while delivering justice. To do this rigorously, governments need to improve their measurement tools. This paper examines the measurement tools employed today in two developing countries-Jamaica and the Dominican Republic - showing how existing data might be analyzed and presented more effectively. We describe the many tactics used by police, prosecutors, and other institutions within the criminal justice system as falling under two broad strategies: (1) removing criminals from society, and (2) reducing the proximate causes of crime. All countries depend on some combination of these two strategies, but while governments tend to favor the first, the second usually produces greater crime reduction. We show how improving five specific performance indicators can help governments reduce the proximate causes of crime, maximizing the contribution of criminal justice systems to public safety.
\end{abstract}

\section{Contents}

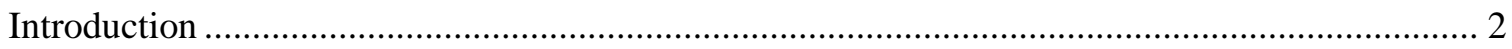

I. Performance Measurement in Criminal Justice Today ............................................................. 4

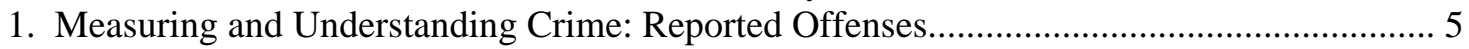

2. Solving Crimes: Clearance Rates for Homicide ............................................................... 7

3. Prosecuting and Adjudicating Cases: Prisoners Awaiting Trial or Sentence......................... 9

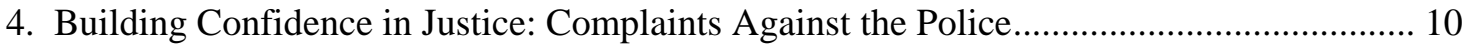

5. Incarcerating Prisoners: Escapes, Deaths, and Violence in Custody .................................. 12

II. Strategies to Reduce Crime and Violence …….................................................................... 14

1. Measuring and Understanding Crime: Mapping Crime Patterns ......................................... 20

2. Solving Crimes: Balancing Arrests for Major and Minor Offenses..................................... 21

3. Prosecuting and Adjudicating Cases: Focusing on Bellwether Crimes ............................... 27

4. Building Confidence in Justice: Focusing on the Poor and Marginalized Groups................ 30

5. Incarcerating Prisoners: Reducing Recidivism .................................................................. 34

III. Conclusion: Governance and the Direction of Criminal Justice Reforms............................... 35

\footnotetext{
${ }^{1}$ Todd Foglesong is Senior Research Fellow and Coordinator of the Justice Systems Workshop at the Kennedy School of Government. Christopher Stone is the Daniel and Florence Guggenheim Professor of the Practice of Criminal Justice, Kennedy School of Government, Harvard University (www.ksg.harvard.edu/criminaljustice). This is an enlarged and substantially revised version of a background paper prepared for the World Bank’s 2007 publication on Crime and Violence in the Caribbean. The authors are grateful to Andres Rengifo and Glendene Lemard for research assistance and their reviews of earlier drafts, as well as to Andrew Morrison and Ted Leggett for their guidance on the original background paper. Special thanks go to the many public officials in Jamaica and the Dominican Republic who generously shared data as well as insights about doing justice and reducing crime.
} 


\section{Introduction}

The contribution of judges, prisons, and even police to the control of crime in any country is a matter of great uncertainty. These institutions may reduce crime, but they may also exacerbate it. Indeed, they may do both at the same time, even while the combined effects are obscured by other factors entirely outside the criminal justice system.

For example, sending some people to prison for armed robbery may deter others from committing similar crimes, but it may also make it more likely that those sent to prison will, after release, persist in crime much longer than they would have otherwise. Even within the short term, arresting some people for narcotics trafficking may reduce the supply of drugs, but it also may throw orderly markets into chaos, increasing violence as new entrants compete for control. In each of these two examples, criminal justice interventions both decrease and increase future crime. At the same time, changing economic opportunities for robbers and drug dealings and changing levels of disapproval of robbery and drug dealing may have greater impact on levels of crime than the formal activities of the justice system. All of this makes it difficult to know whether any particular intervention is working.

Governments facing high levels of crime and violence must act decisively in these circumstances, despite this uncertainty. A few governments wisely do more than this: in addition to decisive action, they simultaneously measure and assess the effectiveness of their efforts. When they do so, they help reduce the uncertainty that haunts this field, giving themselves greater confidence that their criminal justice systems are making a valuable contribution to justice and safety while helping their counterparts globally become smarter about crime policy.

The governments of Jamaica and the Dominican Republic are commendable in these respects. Not only are they acting firmly in the face of very high levels of violent crime, but they are collecting and analyzing data-mostly concerning homicide-in order to better understand whether or not their criminal justice systems-mostly the police-are helping to reduce the violence. Moreover, they are creating mechanisms of governance - positions of authority or strategic councils - charged with using these data and analyses to improve government's response to violent crime.

The fact that the governments of Jamaica and the Dominican Republic are taking these extra steps-collecting and analyzing data, and creating governance structures that could use these analyses to improve the criminal justice interventions-makes them good examples of how measurement in the justice sector can help focus efforts to reduce crime; but we must not overstate what these governments have achieved. Violent crime remains a large problem in these countries. Only a few of the newest measurement tools focus on crime reduction and none of them reveal the combined impact of separate institutions in the justice sector - the police, prosecutors, legal aid, victim services, courts, prisons, oversight commissions, and so on. 
In order to realize the potential in their initial steps, these governments need to draw more power from their measurement systems, integrating measurement with the full range of people, knowledge, and tools that they have assembled across the criminal justice system. A strategic measurement system would encourage the disparate elements of the criminal justice system to work together in closer alignment. It would help the prosecution to reinforce and multiply the effectiveness of the police, rather than inadvertently undermining police actions. It would allow the provision of services to victims of past crimes to contribute to the reduction of future crimes. It would focus the managers of the prisons to participate in the reduction of violence rather than merely try to contain the most serious of those who are charged with crimes for a limited time. A strategic measurement system would, in short, allow a government to align the elements of its criminal justice system — and a better aligned system is more capable of delivering both public safety and justice.

Jamaica and the Dominican Republic are separated by barely 300 miles in the Caribbean, but have highly contrasting criminal justice systems. Jamaica, a country of 2.6 million people, is a parliamentary democracy in the common law tradition. The Dominican Republic with approximately 9 million people, is a presidential republic in the civil law tradition. In each country a single entity provides general police services: the 30,000member National Police in the Dominican Republic, and the 7,000-strong Jamaican Constabulary Force. Both countries have abolished the death penalty.

Happily, the structural differences among the world's criminal justice systems have little to do with their ability to keep people safe or do justice. We focus here on two countries with different systems of governance and justice, not to contrast one with the other or to determine which works better, but rather to illustrate that the same approach to strategic measurement can be used to improve the contribution of either system to safety and justice.

This paper proceeds in two parts. The first part describes how the governments of Jamaica and the Dominican Republic currently conceive and measure the work of justice institutions. Most of the indicators currently in use are activity measures, that is they measure the activities of individual institutions in the justice sector. These activities - for example, arresting people or preventing prisoners from escaping-are assumed a priori to contribute to the reduction of crime or the delivery of justice. In contrast, very few of the current indicators directly measure the reduction in crime or the quality of justice that these activities are thought to produce.

The second part of the paper shows how these governments could use data that they already possess in new ways to create strategic indicators. These would give an indication whether or not safety and justice are actually increasing and by how much. Strategic indicators of this kind would help officials question their own assumptions about how they are contributing to public safety and justice, develop better and more integrated strategies to do so, and then test whether or not the new strategies actually reduce crime and violence. 
The design and implementation of effective strategies are not simple matters. They require agreement about priorities and a more robust set of governance mechanisms to align the work of the justice sector as a whole. But the pieces of well aligned strategy are visible already in current actions and plans, and in both countries the governments have taken initial steps toward stronger governance in the justice sector.

\section{Performance Measurement in Criminal Justice Today}

In both Jamaica and the Dominican Republic, each law enforcement and justice institution records (and sometimes reports) information related to its own tasks and responsibilities. The police, for example, customarily record the number of crimes reported to them, and sometimes the number of arrests by charge and location. The police do not, however, record what happens with these arrests: whether or not the suspects were formally tried, and, if so, whether or not they are convicted. This is typical of practice around the world: with police uninformed as to what the rest of the justice system has done with the people they arrest and the cases they send to prosecutors.

For their parts, the courts and prosecution record the number of trials and appeals, with their outcomes, but they do not calculate what proportion of suspects arrested for any particular offense last year were tried, convicted, or sentenced to imprisonment. Similarly, the prisons record the number of inmates according to the type of crime for which they were admitted, as well as the number of escapes and deaths in custody, but they do not calculate the proportion of sentences actually served. And no one records what happens to people when they are released from custody: whether or not they commit new crimes when they return home.

To measure performance in the justice sector today in both these countries still means to track institutional activities, not to assess how the system as a whole deals with offenses or suspects, and not to measure the impact of the system as a whole on public safety or the rule of law. In this respect, Jamaica and the Dominican Republic are not unusual in the region or in the world.

This appears to be changing. There is dissatisfaction with the traditional approach both from within the institutions of justice and outside them, and there is a considerable amount of ingenuity and invention at work to improve the reliability and utility of information routinely collected. There is also an effort in both countries to introduce more modern and unified systems of case management and information tracking. The governments of Jamaica and the Dominican Republic have not yet selected strategic indicators for these systems (such as reducing the likelihood of repeat victimization for young women in disadvantaged neighborhoods) or apportioned responsibility to institutions for the performance of activities thought to bring about such effects (such as achieving higher levels of confidence and rates of reporting to the police along with more swift and dignified treatment of victims). This is work on the cusp.

To better illustrate the current situation and the future direction of performance measurement in these systems, we provide five examples of how performance indicators 
are used today and the ways officials are trying to improve them. In part two of this paper, we discuss how these and other indicators might be further developed to evaluate the actual contribution of the various institutions and complex operations in the justice system to the reduction of crime and violence. The five examples are:

1. Measuring and Understanding Crime: Reported Offenses

2. Solving Crimes: Clearance Rates for Homicide

3. Prosecuting and Adjudicating Cases: Prisoners Awaiting Trial or Sentence

4. Building Confidence in Justice: Complaints Against the Police

5. Incarcerating Prisoners: Escapes, Deaths, and Violence in Custody

\section{Measuring and Understanding Crime: Reported Offenses}

In both Jamaica and the Dominican Republic, the official measurement of crime is primarily the responsibility of law enforcement agencies. Public health agencies, planning institutes, and statistical offices sometimes play auxiliary roles. Academic and other civil society analyses of crime and its sources are not regularly used by governments.

In the Dominican Republic there is no clear national count of reported crime. The counting of offenses in the Dominican Republic is left to the separate agencies of law enforcement (such as the National Division for the Control of Drugs) and, within the national police, divided up by different divisions responsible for their investigation. These separate institutions use different language, frames, and reports to record these data, making it impossible to sum them all up. ${ }^{2}$ In Jamaica, by contrast, the department of statistics of the Jamaican Constabulary Force (JCF) aggregates information about all reports of crime received from commanders in each parish, and then sorts the data into six categories of "major crimes." This effort yields the following picture of the amount of crime and violence in Jamaica.

\footnotetext{
${ }^{2}$ Within the national police, the function of analyzing crime and violence is greatly dispersed. Beneath the Office of the Chief of Police (Jefatura), there are a few data analysts as well as a Department of Statistics, along with a more recent creation, the Department of Mapping. The Division of Criminal Intelligence (DINTEL), formerly the Secret Service, has its own analytical unit and statistics division. The Division for the Investigation of Crimes (DICRIM) is supported by a Department for the Analysis and Processing of Information, but its subordinate operational investigative units, such as the Departments of Homicide, Robbery, and Auto Theft, also have their own data collectors and analysts. Each of these departments and operations, moreover, receive different quantities and types of information.
} 
Figure 1. Major Crimes Recorded by Jamaican Constabulary Force, 2000-2006

\begin{tabular}{|lccccccc|}
\hline & $\mathbf{2 0 0 6}$ & $\mathbf{2 0 0 5}$ & $\mathbf{2 0 0 4}$ & $\mathbf{2 0 0 3}$ & $\mathbf{2 0 0 2}$ & $\mathbf{2 0 0 1}$ & $\mathbf{2 0 0 0}$ \\
\hline \hline Murder & 1316 & 1674 & 1471 & 975 & 1045 & 1139 & 887 \\
Shooting & 1235 & 1646 & 1675 & 1145 & 1270 & 1183 & 1012 \\
Rape & 681 & 746 & 860 & 931 & 875 & 912 & 870 \\
Carnal Abuse & 462 & 346 & 409 & 377 & 270 & 306 & 434 \\
Robbery & 2154 & 2210 & 2103 & 1710 & 2021 & 2109 & 2331 \\
Breaking & 1312 & 1653 & 2044 & 1401 & 1769 & 2184 & 2426 \\
Larceny & 124 & 186 & 238 & 258 & 251 & 228 & 274 \\
\multicolumn{1}{r}{ Total } & $\mathbf{7 2 8 4}$ & $\mathbf{8 4 6 1}$ & $\mathbf{8 8 0 0}$ & $\mathbf{6 7 9 7}$ & $\mathbf{7 5 0 1}$ & $\mathbf{8 0 6 1}$ & $\mathbf{8 2 3 4}$ \\
\hline
\end{tabular}

* projection, based on reports for January 1-July 16, 2006.

The data show that there were substantial increases in the number of homicides in this period, especially between 2003 and 2005, and this growth was nearly matched by an increase in shootings. The data also show that the number of key property crimes such as breaking and larceny are lower today than in 2000, with a pronounced decline since 2004.

Unfortunately, there is little confidence in the reliability of this information. Although the department of statistics of the JCF cleans these data and is improving the categories into which it is sorted — especially for the various "motives" of murder—one senior police officer told us not to put any faith in any information about crimes other than homicide and perhaps shootings. We know from other research that there is wide underreporting of offenses, especially property crimes. ${ }^{3}$ But the problems here go beyond underreporting, which plagues crime data in every country; officials doubt the reliability even of the figures on reported crime once they are aggregated at the national level. This information thus has limited utility as a measure of crime and violence in Jamaica.

What is a government to do in the absence of a credible measure of the scale of crime and violence? Is meaningful performance evaluation possible without a sound baseline? Can governments identify problems, select targets, and hold themselves accountable for reducing crime and violence without comprehensive information about its true scale?

The governments of Jamaica and the Dominican Republic are experimenting with two ways of evaluating government performance in the midst of uncertainty about the extent of crime and violence. One way is to make homicide the focus of crime reduction efforts: it is the crime about which there is the greatest information as well as heightened public concern and international attention. Later in this paper we discuss some of the advantages and disadvantages of this strategy, which is pronounced in both countries. Here we note that such an approach makes sense as a crime reduction strategy if murder is the greatest source of public insecurity and if reductions in homicide can leverage other gains in public safety.

\footnotetext{
${ }^{3}$ Anthony Harriott, for example, estimates only 25 percent of all incidents are reported to the police. See "Fear of Criminal Victimization in a Reputedly Violent Environment," Social and Economic Studies, volume 52, no. 1 (2003), p. 44.
} 
Another strategy is to use victimization surveys and other sources of knowledge about crime and violence to supplement police data. Although the study of victimization is at an early stage in both Jamaica and the Dominican Republic, officials and researchers in both countries are using this emerging knowledge to shape the priorities of government and the routines of law enforcement. Data on victimization and fear of crime can guide government priorities and action, especially in the communities most vulnerable to crime.

\section{Solving Crimes: Clearance Rates for Homicide}

As in almost all countries, the police in Jamaica and the Dominican Republic routinely measure their clearance or "clear up" rate, but they do not follow their cases through the justice system or otherwise monitor the rates at which arrests yield convictions. ${ }^{4}$

The national police force in the Dominican Republic does not track clearance rates for homicide separately from other crimes against the person (e.g., robbery, assault). It also does not publish this information. Nevertheless, we were able to obtain information compiled by the police about the number of reported violent crimes for which the police had made an arrest for five recent months. As the table in Figure 2 below shows, in the last four months of 2005 and first month of 2006, the police recorded 1643 crimes against the person and made arrests in 33 to 40 percent of these cases.

\section{Figure 2. Clearance Rates for "Crimes Against the Person," Dominican Republic, August 2005-January 2006}

\begin{tabular}{|cccc|} 
Months & $\begin{array}{c}\text { Cases } \\
\text { "Solved" }\end{array}$ & Cases Pending & $\begin{array}{c}\text { Total } \\
\text { Cases }\end{array}$ \\
\hline \hline August & 44 & 83 & 127 \\
September & 111 & 185 & 296 \\
October & 100 & 197 & 297 \\
November & 116 & 168 & 284 \\
December & 132 & 205 & 337 \\
January & 115 & 187 & 302
\end{tabular}

Source: Departamento de Analisis y Procesamiento de Informacion, DICRIM, Policia Nacional

Analysts in DICRIM, the Division for the Investigation of Crimes, are trying to improve this indicator, for in its present form it does not distinguish between old and new cases (eg, one cannot tell what portion of the 111 cases solved in September came from the 83 cases pending in August). They also hope to separate homicide from assault and robbery, which they suspect has a lower rate of clearance, but they have yet to overcome the technical and administrative hurdles to such an assessment.

A more discriminating measure of clearance rates can be composed with data collected by the Statistics Department of the Jamaican Constabulary Force. The table below shows

\footnotetext{
${ }^{4}$ The police consider a crime cleared if a person is arrested for the offense or if they conclude that the crime was committed by a person who subsequently dies. Some police forces also consider a crime cleared if they have named a suspect (usually in an arrest warrant) who has not yet been apprehended.
} 
how this Department sorts reported homicides into categories by "motive" - that is, loosely, the circumstances which a police investigator or statistician consider to have caused the act of violence. ${ }^{5}$ It records clearance rates ("C/up") for each type of newly reported homicide. ${ }^{6}$ Figure Three shows that these vary from a low of zero in cases of gang-related murders in the first six and a half months of 2005, to a high of 83 percent for "other criminal acts" in the same period of 2006.

As a measure of police performance, clearance rates have certain value. When an arrest is made after a period of investigation, and especially upon receipt of a warrant from a judicial officer, "clearance” reflects the hard work of police officers to collect evidence and convince others of the grounding for their suspicions. "Clearances" achieved at the scene of the crime - through witness identification, direct police observation, or even the death of the suspect-are weaker indicators of performance, since they are inflated by good fortune and violent confrontations. ${ }^{7}$ Nevertheless, good police work is reflected in these indicators, and police almost everywhere treat them as a sign of effective policing.

Figure 3: Homicide Clearance Rates in Jamaica by "Murder Motive," 2005 and 2006 (January 1-July 16)

\begin{tabular}{|c|c|c|c|c|c|c|c|c|}
\hline \multirow[b]{3}{*}{ Murder Motive } & \multicolumn{4}{|c|}{2006} & \multicolumn{4}{|c|}{2005} \\
\hline & \multirow[b]{2}{*}{ Reported } & \multicolumn{3}{|c|}{ Clup } & \multirow[b]{2}{*}{ Reported } & \multirow[b]{2}{*}{$\%$ of total } & \multicolumn{2}{|c|}{ Clup } \\
\hline & & $\%$ of total & $\mathbf{N}$ & $\%$ & & & $\mathbf{N}$ & $\%$ \\
\hline Drug Related & 10 & $2 \%$ & $\overline{111}$ & 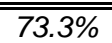 & 10 & $2 \%$ & 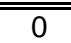 & $0.0 \%$ \\
\hline Gang Related & 159 & $22 \%$ & 44 & $27.7 \%$ & 224 & $24 \%$ & 61 & $27.2 \%$ \\
\hline Domestic & 22 & $3 \%$ & 14 & $63.6 \%$ & 26 & $3 \%$ & 18 & $69.2 \%$ \\
\hline Other Criminal Act & 335 & $47 \%$ & 278 & $83.0 \%$ & 423 & $46 \%$ & 260 & $61.5 \%$ \\
\hline Not Yet Established & 182 & $26 \%$ & 0 & $0.0 \%$ & 240 & $26 \%$ & 0 & $0.0 \%$ \\
\hline \begin{tabular}{|l} 
Total \\
\end{tabular} & 713 & $100 \%$ & 347 & $48.7 \%$ & 928 & $100 \%$ & 339 & $36.5 \%$ \\
\hline
\end{tabular}

Source: Department of Statistics, Jamaican Constabulary Force

These same data on clearance rates would provide better measures still if they helped the police measure the equity in their policing and the strengthening of their adherence to certain human rights standards. For example, police statisticians could develop a measure of equity by distinguishing between arrests made in poor versus affluent districts. They could also calculate a ratio of arrests of suspects to deaths of suspects within key crime categories, providing an indicator of compliance with human rights standards about the use of lethal force in responding to crime. We return to this indicator in part two of this chapter when we consider additional improvements that would allow the police also to measure the contribution of arrests to crime reduction.

\footnotetext{
5 The deputy director of the statistics department explained that, in reviewing police reports of homicide and other crimes, the disparity between the reported facts of the case and the account of the investigator sometimes compel him to redefine the motive for the murder. Personal interview, July 17, 2006.

${ }^{6}$ A separate table tracks the number of murders from "previous years" that are cleared.

${ }^{7}$ Some police forces, including the JCF, consider a crime cleared if the suspect is killed. In nearly onequarter of the cases of robberies considered cleared by the JCF, the suspect had been killed by police officers or civilians.
} 


\section{Prosecuting and Adjudicating Cases: Prisoners Awaiting Trial or Sentence}

Like their counterparts in almost every country of the world, government statisticians in Jamaica and the Dominican Republic calculate and report the proportion of inmates in custody who have not been tried or sentenced. We focus here on the Dominican Republic, for which the data available are more precise.

Between May 2003 and September 2004, when a new code of criminal procedure was introduced, the total population in custody in the Dominican Republic declined from 16,491 inmates to 12,805 . As the graph below shows, most of this reduction came from the ranks of un-sentenced inmates and the number awaiting the outcome of appeals. ${ }^{8}$ From September 2004 through May 2006, however, there has been no major change in the number of inmates. The number of un-sentenced prisoners initially declined, but then rose again toward the end of 2005, and this group still comprises nearly 70 percent of all persons in custody. ${ }^{9}$

\section{Figure 4: Sentenced and Un-sentenced Prison Inmates, Dominican Republic, May 2003 to May 2006}

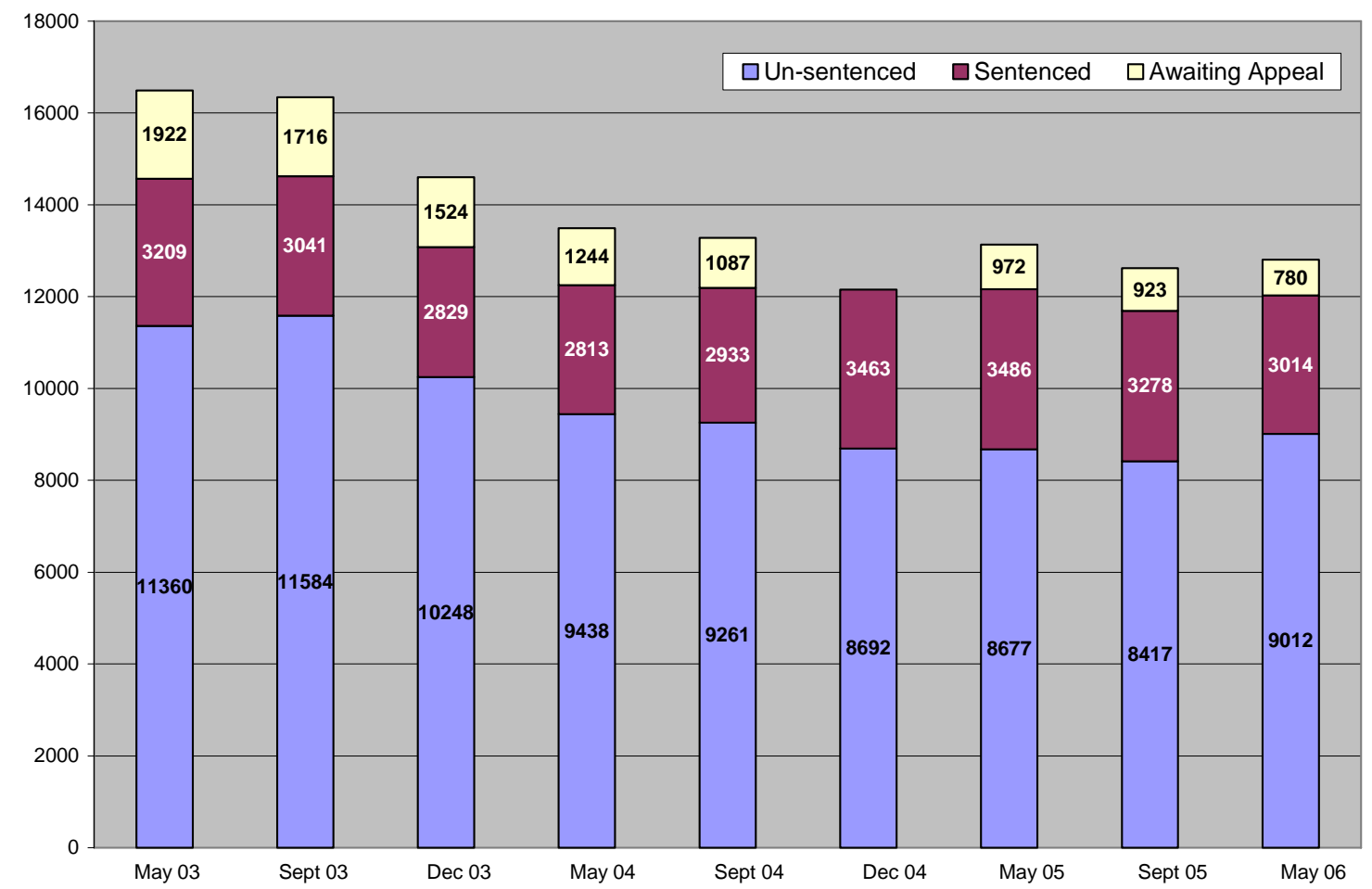

Source; Dirección Nacional de Prisiones, Procuraduría General de la Republica

This indicator is widely reported by governments around the world and cited by reformers because it is relatively easy for prison administrations or inspectors to

\footnotetext{
${ }^{8}$ On average, another 100 to 140 inmates were in custody each day pending the ruling of a cassation court.

${ }^{9}$ Prisons in general also still substantially over-crowded: the system has a legal capacity of just over 9,000.
} 
calculate, but not because it is especially revealing. To the contrary, this is a highly ambiguous indicator. For example, the downward trend from May 2003 to September 2004 may reflect an improvement in the work of prosecutors or judges, if they are adjudicating cases more quickly; but the same trend could be explained by a reduction in arrests for serious cases that typically take longer to adjudicate. Similarly, the increase since December 2004 in the number and proportion of un-sentenced inmates in the Dominican Republic may reflect an increase in the amount of time it takes to prosecute and adjudicate defendants - a sign possibly of the deterioration of productivity and performance of the justice system; but it could equally well reflect an increase in the number of arrests in serious cases without a corresponding improvement in judicial performance. Even more confounding, the same data could also be explained by a constant level of arrests and a constant speed of adjudication but a higher rate of pretrial detention as sometimes occurs after a particularly notorious crime or a particularly embarrassing failure by prosecutors to win a conviction against a notorious offender.

The statisticians in the offices of the Procurator General and Supreme Court of the Dominican Republic are diligently attempting to improve this indicator in ways that would reduce its ambiguity. They have recently produced data that show a relatively low use of pretrial detention (approximately 5,318 orders of pretrial detention compared with approximately 12,237 defendants presented to the courts on arrest warrants in the first year of the operation of the reforms). The statisticians in the Supreme Court are currently attempting to improve the indicator further by collecting information on the number of requests for detention made by prosecutors. Reporting these statistics on a regular basis would put the Dominican Republic into the forefront of prosecution and court systems making sophisticated use of such data.

\section{Building Confidence in Justice: Complaints Against the Police}

In Jamaica, two separate bodies collect complaints from civilians against the police: a Department of Internal Affairs within the JCF and the Police Public Complaints Authority (PPCA) within the Ministry of Justice. There is no public information about the work of either of these entities. ${ }^{10}$ Still, there are signs that the government of Jamaica is trying to improve their effectiveness as accountability mechanisms. The National Security Strategy for Jamaica, promulgated by the Ministry of National Security in May 2006, recommends that, as part of the strategic review of the JCF, there be an assessment that would "examine legislative and higher level administrative structures, such as the Police Services Commission (PSC) and Police Public Complaints Authority (PPCA), in order to facilitate an effective civilian oversight mechanism for proper accountability for its performance and conduct."11

\footnotetext{
${ }^{10}$ We attempted, unsuccessfully, to obtain data from these bodies informally in time for inclusion in this publication.

${ }^{11}$ See "National Security Strategy for Jamaica: Towards a Secure and Prosperous Nation. A Green Paper" prepared by the Ministry of National Security, May 2006, p. 53. This document is available at: www.cabinet.gov.jm/docs/pdf/NSS_DOCS/NSS_DOC.pdf
} 
In the Dominican Republic, the Office of Internal Affairs is charged with holding police accountable for misconduct. Its director is appointed by the President, not the Chief of Police, and thus enjoys some independence and autonomy. This office has an independent investigative capacity within its staff of 214 , although its resources are stretched. It can initiate its own investigations as well as act on complaints it receives from the public. The office has shown remarkable ingenuity in reducing the costs and frustrations of investigating specific instances of past misconduct by responding to most complaints where the police officer is identified by ordering a drug test of the officer. A test revealing drug use obviates the need to complete the more difficult investigation of past misconduct.

A further sign of determination in the office is its use of the courts. In the past, when this office recommended disciplinary proceedings against police officers, these were typically adjudicated by a police tribunal. Increasingly today, however, according to General Daisy Liriano, the new director, complaints substantiated by the office are brought before ordinary courts.

Between August 2005 and May 2006, the period for which we have detailed information, the department received 637 complaints, an average of two per day. Nearly threequarters of these complaints were substantiated through investigations, an extraordinarily high percentage for any country. Just over half of the complaints (319) involved allegations of physical aggression or death threats by officers.

These indicators suggest that the Office of Internal Affairs is admirably focused on holding individual police officers accountable to professional standards. The promised addition to the police service of 15,000 new officers in the next few years will make that effort all the more important.

The office is currently designing a stronger information management system, which should improve both the reliability and the range of data available for performance measurement. If that new system were to include information (currently not recorded) about the complainants, it would allow the office to measure the equity in its own responsiveness, especially to poor and vulnerable groups. We were told, for example, that the majority of complainants are friends and family members of people allegedly mistreated by the police rather than the victims themselves, but no data are systematically collected about these complainants.

Beyond such immediate improvements, this office might also begin to chart changes in public confidence in the police and the wider justice system, a possibility we will consider again in part two when we turn to the effectiveness of the system in reducing crime and violence.

In addition, in neither Jamaica nor the Dominican Republic do the formal accountability mechanisms reach beyond oversight of the police. There is no national justice commissioner or ombudsman for the receipt and investigation of complaints against criminal justice systems more widely. In the Dominican Republic, complainants can turn 
to the Interamerican Court of Human Rights. In Jamaica, complainants have only the Supreme Court or the offending government department itself.

\section{Incarcerating Prisoners: Escapes, Deaths, and Violence in Custody}

Prison administrations around the world assume that they contribute to public safety by preventing their prisoners from escaping. The better administrations also seek to incarcerate their prisoners safely, minimizing violence and deaths in custody. Both countries considered here produce indicators on both of these dimensions: measuring some form of violence in custody as well as the number of escapes.

The graph in Figure Five shows the indicators measured in the Dominican Republic, including deaths in custody (but not non-lethal violence). The indicators are difficult to interpret in this form because they show absolute numbers rather than rates per prison population. As we have seen in the earlier discussion of pretrial detention, the prison population in the Dominican Republic was substantially higher in 2003 than the stable level it maintained from 2004 through mid-2006. When recalculated as rates, the level of deaths in custody appears to be steadily increasing from 48 deaths per 10,000 prisoners in 2003, to 58 in 2004, and to 68 in 2005. The figures for the first five months of 2006 suggest that the prisons may be experiencing their first decline in recent years, back down to an annual rate of 49 deaths per 10,000 prisoners. The prison administration does not report the reasons and circumstances of these deaths, so we cannot assess the relative contribution of crowding, illness, and violence to these problems.

\section{Figure 5: Prison Deaths, Escapes, and Recaptures, Dominican Republic}

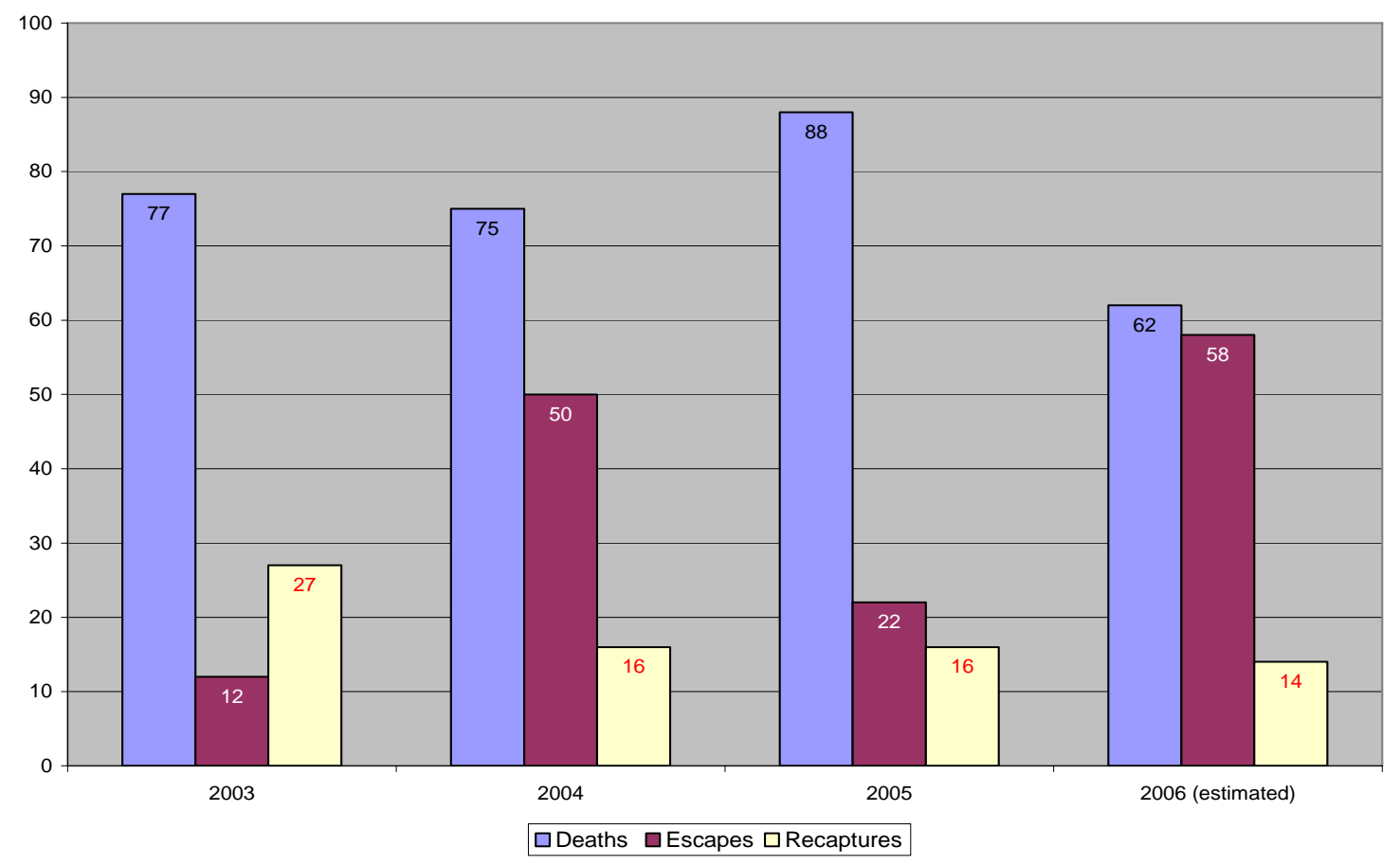

Source: Dirección General de Prisiones, Procuraduría General de la Republica

Notes: In 2005, an additional 138 inmates died during a fire. 2006 is estimated on the first five months of the year. 
The changes in the number of escapes are perplexing whether or not these are calculated as rates. The huge annual swings in the numbers of escapes reported make any comparisons with other countries meaningless, since the security of the prisons will seem relatively loose or tight depending on the year. ${ }^{12}$

The Department of Correctional Services in Jamaica also tracks this kind of information with additional detail, including the level of non-lethal violence. The prisons in Jamaica report substantial reductions from five years ago in both the number of unnatural deaths and the number of violent incidents in custody. In 2001, there were 17 unnatural fatalities out of a total of 33 deaths in prison. In 2005, there were 8 unnatural deaths out of a total of 20. In 2000, there were 153 violent incidents reported in adult institutions. This number decreased to 92 in 2005. The numbers of violent incidents appears to have increased in 2004 and again in 2005, but the Director of the Department of Correctional Services attributes this to better systems of reporting. There were seven escapes from prison in 2004, and none the following year, although an allegedly "massive escape" from the Tower Street facility was apparently foiled in 2005. ${ }^{13}$ The graph in Figure Six records some of this information.

\section{Figure 6. Unnatural Deaths and Violence in Jamaican Prisons, 2000-2005}

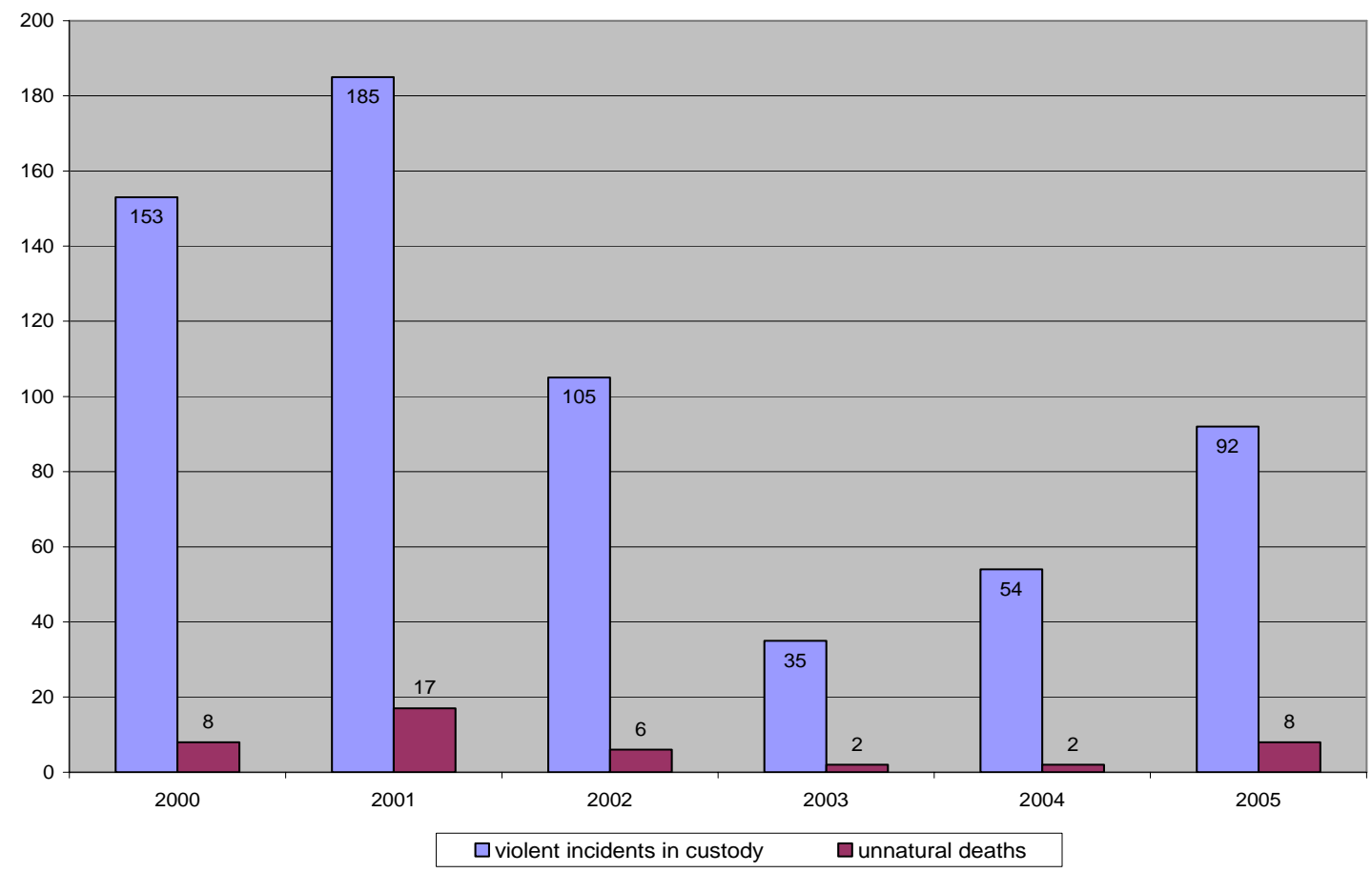

Source: Department of Correctional Services, Annual Report, 2005.

The Department of Correctional Services in Jamaica is eager to develop a wider range of indicators, including indicators of recidivism. We return to this issue in part two, but we

\footnotetext{
${ }^{12}$ The number of "recaptures" in 2003 exceeds the total number of escapes because of a large number of escapes in the preceding years.

${ }^{13}$ Some of this information is now available on the website of the Department of Correctional Services, http://www.dcsj.net/p/stats.htm
} 
note here how difficult this is for an institution in any country's justice system operating on its own. The Department is beginning to collect and report information on the number of persons admitted to prison who have previously been incarcerated. At first glance, an increase in this number might appear to reflect an increase in recidivism, but it is equally or more likely to reflect changes in the performance of other institutions of the system. For example, if increases in the numbers of police lead to increases in arrests, the numbers of prisoners with prior incarcerations should increase. If sentencing legislation is toughened, if prosecutors become more aggressive in their charging decisions or more effective at obtaining convictions, or if judges become more punitive in their sentencing, the result will be an increase in the number of prisoners with prior records of incarceration, even if recidivism remains flat. Perhaps most likely of all, if community surveillance of people returning from prison becomes more effective-as is occurring in almost every country - then returning prisoners will be especially vulnerable to re-arrest and re-incarceration, creating a false impression of rising recidivism.

The Jamaican Department of Correctional Services is attempting, with this new indicator, to measure exactly what it should measure: the contribution of the prisons to the reduction of recidivism and, implicitly, to the increase of public safety. The problem is not its ambition, but its poor position in the justice system to carry out this task. Prisons are too remote from fresh acts of crime and violence to suppress these on their own.

For this reason, we now turn to the question we have been putting off: do any of the activities of these justice and law enforcement agencies really make the people of Jamaica and the Dominican Republic safer? What is the contribution of these activities to the reduction of crime and violence? And how might officials in these countries begin to answer that question with the data available to them today?

\section{Strategies to Reduce Crime and Violence}

Could the criminal justice systems in these two countries be doing more to reduce crime and violence? That question invites officials and observers to look beyond the indicators discussed above, and to delve more deeply into the mechanisms by which the activities of the justice sector actually contribute to reductions in crime and violence. In countries around the world, officials are asking themselves such questions, producing a global shift of strategic thinking within criminal justice. Enterprising officials in Jamaica and the Dominican Republic are working hard to keep up with these trends while they confront particularly high levels of crime and violence.

How does the work of police, prosecutors, courts, prisons, victim services, and various oversight bodies within the criminal justice system actually contribute to reductions in crime and violence? If police cleared up more homicides, if prosecutors and courts made different choices about whom to detain before trial and for how long, if prisons allowed fewer escapes or reduced the level of violence inside the walls, and if oversight bodies responded more vigorously to complaints against the police, would crime and violence reliably decline? And are there other things that these components of the system might be doing that would be more effective at reducing crime and violence? 
The indicators discussed above cannot answer those questions. Counting the number of homicides cleared up does not tell us how many homicides have been prevented. Indeed, it tells us nothing about whether a focus on homicides or robberies would be more effective at reducing the overall level of violence in one or the other of these countries.

To answer these questions, we first make explicit the two dominant strategic ambitions that attempt to connect the work of criminal justice and law enforcement departments to reductions in crime and violence. We then discuss how these two countries might use their existing data and resources to build a new generation of performance measures that could be used to improve the effectiveness of these strategies.

There are at least two distinct and competing strategic ambitions through which justice institutions try to reduce crime, and both are at work in the Caribbean today. Each of these two competing paradigms provides an account of how the police can contribute to the reduction of crime and violence, each has clear implications for the role of the rest of the criminal justice system, and each carries certain implications for how we should measure the effectiveness of the police and other criminal justice institutions. Both strategic ambitions can be found alongside each other in most countries, but they appear to make quite different contributions to the reduction of crime and violence.

The first strategy is - to put it crudely - to remove as many criminals as possible from society. Under this strategy, the criminals could be imprisoned, deported, or even killed. The underlying assumption behind this strategy is that the criminal justice system contributes to the reduction of crime and violence by removing individual criminals. In a well integrated and efficient criminal justice system, this could be done by maximizing arrests, convictions, and lengthy prison sentences. In a broken criminal justice system, the police will be tempted to remove the criminals themselves: often brutally and often with popular support.

The second strategy is to eliminate the immediate conditions that permit crime and violence to thrive: to solve the proximate underlying causes of crime. This is not about reducing poverty, illiteracy, inequality, or other social conditions that may cause crime, but rather eliminating the immediate conditions on streets and in neighborhoods that allow violence to flourish, such as competition between criminal gangs, the linkages between drugs and crime, or the widespread possession of guns. In a well integrated and efficient criminal justice system, this would be done through careful crime analysis to identify the crime patterns that might be disrupted, making strategic use of arrest powers to suppress key offenses, building public confidence in the criminal justice system to encourage more civilian participation in crime suppression, and so on.

These two strategies and their implications for the roles of the police and other justice agencies along with common performance measures are summarized in Figure Seven. 
Figure 7. Two Strategies and their Implications

\begin{tabular}{|c|c|c|c|}
\hline & Role of the Police & $\begin{array}{l}\text { Role of the Wider } \\
\text { Justice System }\end{array}$ & Measurable Tactics \\
\hline $\begin{array}{r}\text { Strategy } 1 \\
\text { Remove } \\
\text { Criminals } \\
\text { from Society }\end{array}$ & $\begin{array}{l}\text { Apprehend as } \\
\text { many of the most } \\
\text { serious criminals as } \\
\text { possible }\end{array}$ & $\begin{array}{l}\text { Convict as many } \\
\text { serious criminals as } \\
\text { possible and } \\
\text { incapacitate them for } \\
\text { as long as possible }\end{array}$ & $\begin{array}{l}-\quad \text { Maximize the clearance rate } \\
\text { for the most serious crimes } \\
\text { - } \quad \text { Maximum the conviction rate } \\
\text { in serious cases } \\
\text { - } \quad \text { Maximize sentence length in } \\
\text { those cases } \\
\text { - Minimize recidivism among } \\
\text { those leaving prison }\end{array}$ \\
\hline $\begin{array}{r}\text { Strategy } 2 \\
\text { Eliminate the } \\
\text { Proximate } \\
\text { Causes of } \\
\text { Crime and } \\
\text { Violence }\end{array}$ & $\begin{array}{l}\text { Analyze crime } \\
\text { patterns and use } \\
\text { arrest powers } \\
\text { strategically to } \\
\text { suppress key major } \\
\text { and minor offenses }\end{array}$ & $\begin{array}{l}\text { Build public } \\
\text { confidence in fairness } \\
\text { of criminal justice and } \\
\text { contribute to the } \\
\text { solution of problems } \\
\text { causing key offences }\end{array}$ & $\begin{array}{l}\text { - } \quad \text { Maximize public confidence in } \\
\text { the criminal justice system } \\
\text { - Balance the use of arrest for } \\
\text { major and minor crimes } \\
\text { - } \quad \text { Maximize judicial review of } \\
\text { arrests } \\
\text { - } \quad \begin{array}{l}\text { Produce continuing } \\
\text { reductions in bellwether } \\
\text { crimes }\end{array} \\
\end{array}$ \\
\hline
\end{tabular}

The first strategy_removing criminals - is very popular and widely practiced all over the world. It is hard to imagine any criminal justice system that does not rely in part on such a strategy. Yet this strategy, when relied upon heavily, has two drawbacks. First, the strategy of removing criminals can quickly slip out from under the rule of law and respect for fundamental human rights. Second, the strategy is not particularly good at reducing aggregate levels of crime. Removing individual, serious criminals from society, usually temporarily, is important for many reasons - it reinforces the meaning of the law, holds offenders accountable for their crimes, and dissuades victims of crime from taking the law into their own hands - but it probably has only a marginal effect on future crime rates. Each of these two drawbacks deserves closer examination.

In its most rights-conscious form, the removal of major criminals from free society involves the arrest, trial, conviction, and sentencing of those suspected of the most violent crimes. But where the police and public officials who supervise the justice system have little confidence in the ability of the courts to produce convictions or the ability of the correctional system to protect society from convicted offenders, the same strategy can abandon any commitment to human rights or the rule of law and adopt a more brutal form: the killing of suspected criminals by police in the course of law enforcement actions. In 2005, there were 168 such killings in Jamaica. An additional 133 non-fatal shootings stemmed from what the Jamaican Constabulary Force records as "confrontations" between criminal suspects and members of the police. ${ }^{14}$ In the same year in the Dominican Republic, there were 437 police killings, an average of 36 per

\footnotetext{
${ }^{14}$ According to the UN Rapporteur on extra-judicial killings, the problem with police killings is not limited to rogue officers but rather has complex roots. Based on her visit to Jamaica, the Rapportuer reported "Some sources also claimed that a number of killings by the police were due to corruption within the JCF and the involvement of some police officers with criminal elements." See Report of the Special Rapporteur, Asma Jahangir, submitted pursuant to Commission on Human Rights resolution 2003/53, http://daccessdds.un.org/doc/UNDOC/GEN/G03/162/17/PDF/G0316217.pdf?OpenElement
} 
month or three each day. The year before, there were 510 police killings, equivalent to the average homicide rate for the last twenty years in Costa Rica of 5.6 per 100,000 population. ${ }^{15}$ No account of criminal justice in these two countries can reasonably ignore this brutal side of law enforcement.

It is commonplace to criticize police killings for their disregard of human rights and the rule of law, but it is equally important to point out that there is no evidence that it works as a crime control strategy. The data displayed in Figure Eight below depict the number of recorded homicides and documented police killings each month in the last two years in the Dominican Republic. The number of police killings declined from a high of 58 in July 2005 to a low of 18, while the number of homicides remained fairly stable, at least until May 2006. More importantly, these numbers move in the opposite direction for half of the 24 months captured here, and in the same direction for the other half. Even accounting for a possible time lag between killings and homicides, or homicides and killings, it is difficult to conclude there is a causal relationship between such events. ${ }^{16}$

\section{Figure 8. Homicides and Police Killings in the Dominican Republic, 2005- 2006}

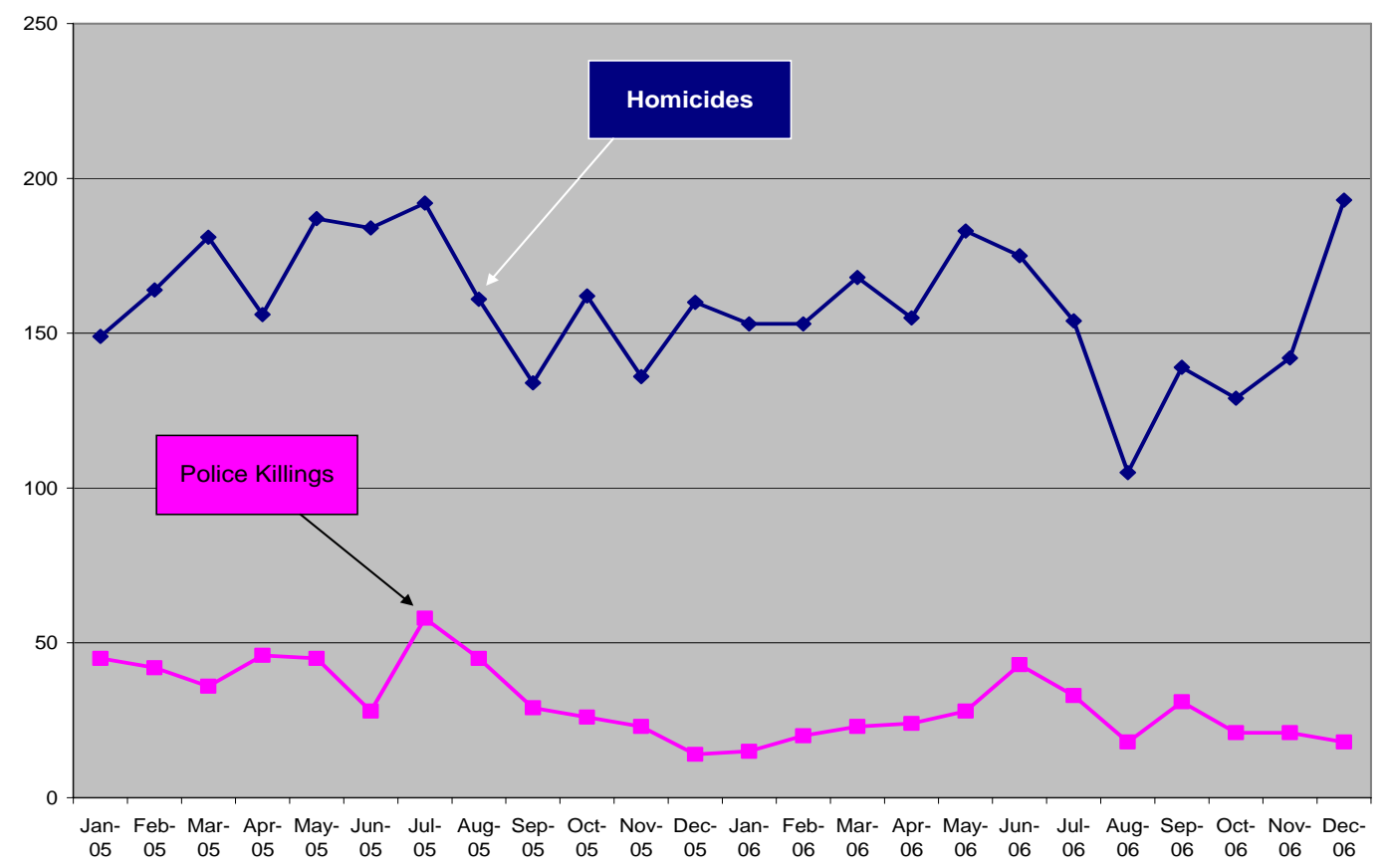

Source: Procuraduría General, Republica Dominicana

\footnotetext{
${ }^{15}$ For a comparison of homicide rates around the world, see Mark Shaw, et.al, "Determining Trends in Global Crime and Justice: An Overview of Results from the UN Surveys of Crime Trends and Operations of Criminal Justice Systems,” www.unodc.org/pdf/crime/forum/forum3_Art2.pdf

${ }^{16}$ Some criminologists assert there is a statistically significant but weak relationship between "justifiable homicide" by civilians, on the one hand, and police killings on the other. These scholars do not claim that police shootings of civilians affect murder rates, however; they merely report that these figures move together over time. For a recent study using aggregate data from the United States, see "The Temporal Relationship Between Police Killings of Civilians and Criminal Homicide: A Refined Version of the Danger-Perception Theory,” J.M. MacDonald, et. al., Crime and Delinquency, 2001, 47, at 155.
} 
The aggregate data for Jamaica also do not suggest a reliable relationship between the killing of criminals and the reduction of violence, but the data here are more ambiguous. As Figure Nine shows, from 1998 through 2002 the number of people killed by police remained high and constant, while homicide went up and down, belying any relationship between the two. Did the doubling of the pace of killings by the police from 2004 to mid2006 contribute to the decline in homicides in the first half of 2006? It is possible, but unlikely, as no earlier data provides any support for such a conclusion.

\section{Figure 9. Homicides and Police Killings, Jamaica, 1998-2006}

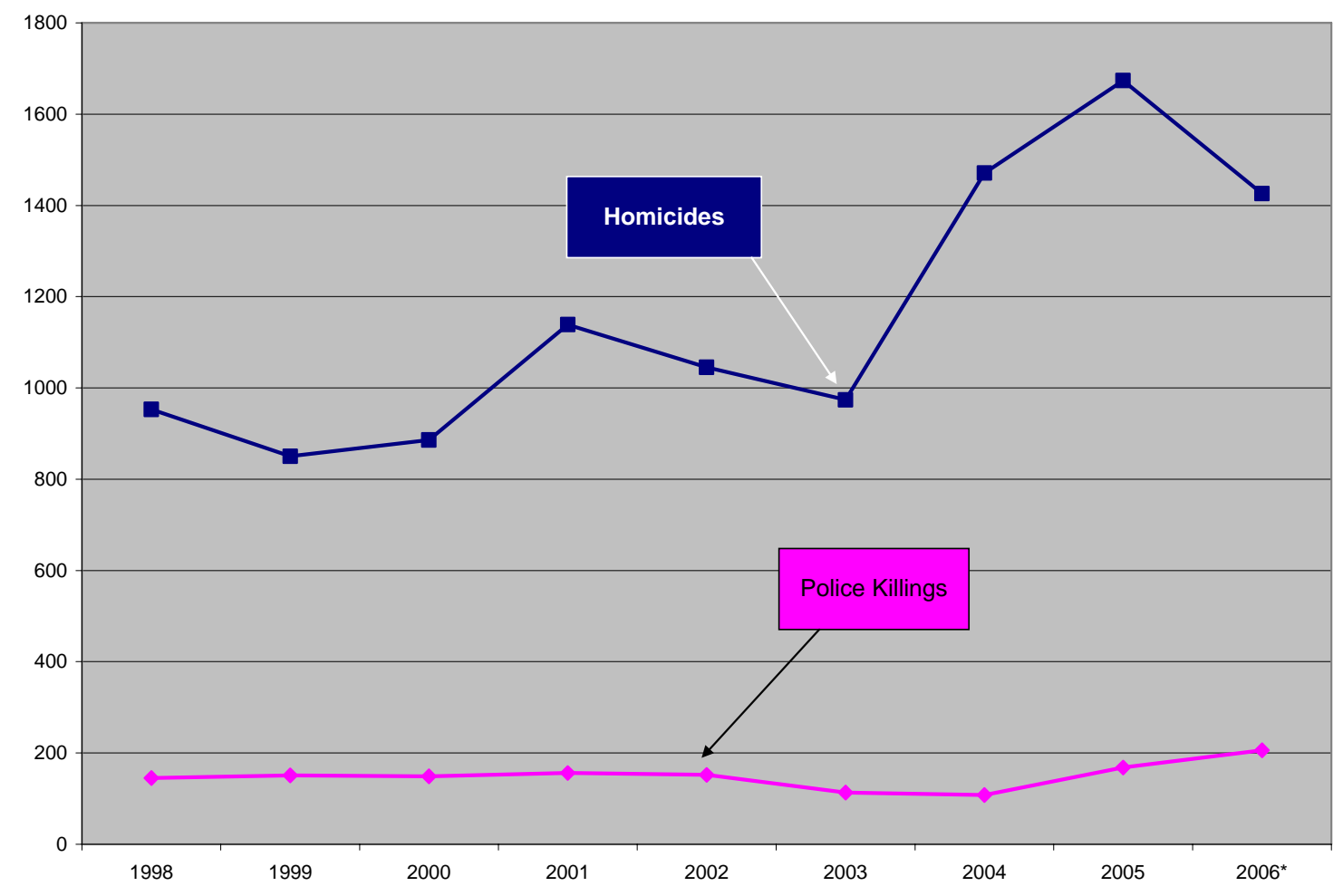

There is, in short, no evidence that the brutal form of Strategy 1 makes a positive net contribution to public safety. ${ }^{17}$

What about the less brutal form of removing criminals from society, in which criminals are arrested, convicted, imprisoned, and sometimes deported? Neither of these two countries is in a position to assess such a strategy as neither country today collects or

\footnotetext{
${ }^{17}$ It is sometimes suggested that killings by the police should be assessed against the number of police who are themselves killed by criminals, and that where a large number of police are killed an even larger number of killings by the police might be reasonable. This suggestion proceeds from the assumption that the police are responding to lethal force by those whom they seek to apprehend. It is also possible, however, that killings of police rise in response to the use of lethal force by police during enforcement actions. In such a scenario, killings by police may escalate a lethal cycle of violence in which both police and criminal suspects die in increasing numbers.
} 
analyzes the data necessary to evaluate the effect on crime of the apprehension, conviction, and imprisonment of offenders. Both governments would need more consistently to track and report the proportion of suspects apprehended for key crimes, the number that are convicted, and the length of their sentences in order to assess this version of the strategy. It would also be useful to measure the effect of incarceration on rates of future offending. ${ }^{18}$

Even as a serious assessment is made of the effect on crime levels of the arrest, prosecution, and incarceration of offenders, experience in other countries suggests that hopes should remain modest. Less than 20 years ago, David Bayley, a leading scholar of policing in several countries, summarized the state of the evidence by writing simply that the police do not reduce crime and that the notion that they do reduce crime levels is "a myth.” As he put it, "the primary strategies adopted by modern police have been shown to have little or no effect on crime." 19 There is a similar skepticism about the role of imprisonment, with the most recent studies suggesting that even in the United States, the world's leading user of imprisonment, a ten percent increase in imprisonment is unlikely to produce more than a 2 -to-4 percent reduction in crime. ${ }^{20}$

Since Bayley's pronouncement, police and justice institutions around the world have begun to develop a series of new tactics that might prove more effective at reducing crime levels. Most of these fall within the terms of what we call Strategy 2: reducing the proximate causes of crime. Those tactics still require much refinement, as well as new work to evaluate their overall impact and consequences. But there is a growing consensus that Strategy 2 can work: at least to reduce specific crimes in specific places over limited periods of time. ${ }^{21}$

The question to which we now turn, therefore, is how the police and the criminal justice system might address the proximate causes of crime in ways that could be expected to lead to the reduction of crime and violence in the Caribbean.

The governments of both Jamaica and the Dominican Republic have launched efforts to tackle both the underlying and proximate causes of crime, including poverty, poor education systems, and stifled social mobility, as well as the proliferation of guns, gangs, fear of the police, and poor regulation of the trade in drugs and alcohol. These governments also have promised to evaluate the impact of such efforts on perceptions of fairness and the legitimacy of the justice system as an integral part of public safety

\footnotetext{
${ }^{18}$ In both Jamaica and the Dominican Republic, justice officials are currently building better systems of tracking, but in neither country was it possible through our research to ascertain the proportion of all murder suspects that have been arrested, prosecuted, and convicted or otherwise prevented from further crime and violence. Some officials requested assistance with such an investigation in the future.

${ }^{19}$ David H. Bayley, Police for the Future (New York, Oxford Univ. Press, 1994), page 3.

${ }^{20}$ For a recent review of this literature, see Don Stemen, Reconsidering Incarceration: New Directions for Reducing Crime, Vera Institute of Justice, 2007.

${ }^{21}$ For the most recent debates about the strengths and weaknesses of these strategies, see David Weisburd and Anthony A. Braga’s “Introduction” to their Police Innovation: Contrasting Perspectives (Cambridge: Cambridge Univ. Press, 2006).
} 
programming. The most recent National Security Strategy for Jamaica, blessed by the outgoing Prime Minister, insists, for example, that

There is need for an effective CJS [criminal justice system] which is accountable and demonstrates fairness in the way people are treated and decisions made... Upholding the rule of law will serve the interest of both primary and secondary violence prevention, public disorder and any disillusionment about the quality and exercise of justice. $^{22}$

The National Plan for Democratic Safety in the Dominican Republic likewise promises to introduce new forms of policing that reflect civic concerns and community interests, and also to ensure that the grand reforms of prosecution, courts, and prisons, introduced in September 2004, uphold public confidence at the same time as contributing to public safety. ${ }^{23}$ As Dominguez Brito, the former Prosecutor General explained in the government's “Contours of Criminal Justice Policy, "the reforms are not directed at the reduction of delinquency as is customarily thought, but rather at the protection of fundamental rights against every type of arbitrary act or violence with criminal relevance." 24

How are these strategies being implemented, and what are their effects so far? The governments of Jamaica and the Dominican Republic are only beginning to establish appropriate performance measures for these strategies, and they have yet to assess the contribution of actions taken by one institution of their justice systems on others. Still, these governments already collect data that can be used to assess the contribution of these more sophisticated strategies to the reduction of crime and violence.

We return, here, to the five examples discussed in Part One, each representing a tactic that could be extended to serve a strategy of eliminating proximate causes of crime. For each, we examine how existing data might be used to measure the effectiveness of tactics that hope to advance this strategy. Finally, we turn to issues of governance and to the structures that each country is putting in place to drive this new strategic approach.

\section{Measuring and Understanding Crime: Mapping Crime Patterns}

We have seen, above, that both countries are trying to cope with crime statistics that are themselves of doubtful validity. Yet even as they improve the quality of these data, officials in the Dominican Republic are experimenting with ways of using the data that allow them to see more deeply into the proximate causes of crime that law enforcement

\footnotetext{
${ }^{22}$ See the Green Paper prepared by the Ministry of National Security, "National Security Strategy for Jamaica: Toward a Secure and Prosperous Nation,” Revised May 2006, p. 57, available at: www.cabinet.gov.jm/docs/pdf/NSS_DOCS/NSS_DOC.pdf

${ }^{23}$ In September 2004, the justice system began operating under a new code of criminal procedure which, among other things, introduced greater restrictions and controls on the use of coercion at all stages of the criminal justice process. The office of the prosecutor general is only beginning to design appropriate systems for evaluating its impact and monitoring key performance indicators, such as conviction rates.

${ }^{24}$ See "Lineamientos de la Politica Criminal dentro de los parametros del Plan Nacioneal de Seguridad Democratica para la Republica Dominicana,” available at: www.procuraduria.gov.do/PGR.NET/Index.aspx
} 
might then target. Specifically, the police in the Dominican Republic are beginning to track the level, timing, and movement of violent crime in and between the "safe neighborhoods" of Santo Domingo, using digitalized maps and census data from the National Office of Statistics. An initial draft of a "calendar of crime," prepared by the Unit for the Analysis and Processing of Information within DICRIM, records the time and days in which offenses committed in public in each of the neighborhoods tend to occur. $^{25}$

These efforts to measure and understand crime are promising not only because the police can adjust the frequency, routes, and number of officers on patrol in response to this analysis, thereby increasing the efficiency of deployments, but also because public groups and merchants can use this knowledge to independently avert victimization and more effectively participate in efforts to reduce crime. These and other innovations could be used not only to guide performance evaluation for the police, but also to monitor changes in levels of confidence and participation in the justice system as a whole.

\section{Solving Crimes: Balancing Arrests for Major and Minor Offenses}

All governments arrest people, but they do so in very different patterns and for different strategic reasons. Arrests can focus solely on the most serious crimes, or they can concentrate on minor offenses that are thought to lead to major offenses. They can be used solely to bring suspects to court, or they can be used to remove people briefly to police stations. Because the police often conceive of arrest as the end of their work, prosecutors and courts see it as the beginning, and the work of managers of jails and prisons can be burdened by unnecessary arrests, governments need impartial assessments of the system-level impact of arrest on crime and justice.

This assessment must answer a variety of questions about the volume and purposes of arrest. Are arrests concentrated in neighborhoods with the greatest proportion of violent offenses? Is it a tool of crime suppression, a mechanism of accountability on its own? What proportion of arrests culminates in prosecution and further detention? Is arrest a means of bringing a suspect to justice or an investigative device, a means of unearthing information otherwise inaccessible to the justice system? How often are arrests reviewed by independent authorities? For both crime reduction and the rule of law, what happens after an arrest is as important as what transpires before it.

The number of arrests made each day in the Dominican Republic is highly volatile. Figure Ten below depicts this volatility, ranging in the first half of 2006 from a low of 15 on March 15 to a high of 326 on April 6. Although the police do not currently tally all arrests or report them by offense, we estimate that there are approximately 55,000 and arrests each year in the Dominican Republic. ${ }^{26}$

\footnotetext{
${ }^{25}$ These efforts are being supported by a partnership between John Jay College of Criminal Justice and the Secretary of the State of Interior and Police of the Dominican Republic. See the report on the website of the Ministry, www.seip.gov.do/2006/web/acuerdos_documentos.php

${ }^{26}$ A report from the Department of Statistics of the Supreme Court indicates there were 16,135 arrests in the third trimester of 2005, and another 11,023 in the first quarter of 2006.
} 
Figure 10. Arrests in the Dominican Republic, February to May, 2006

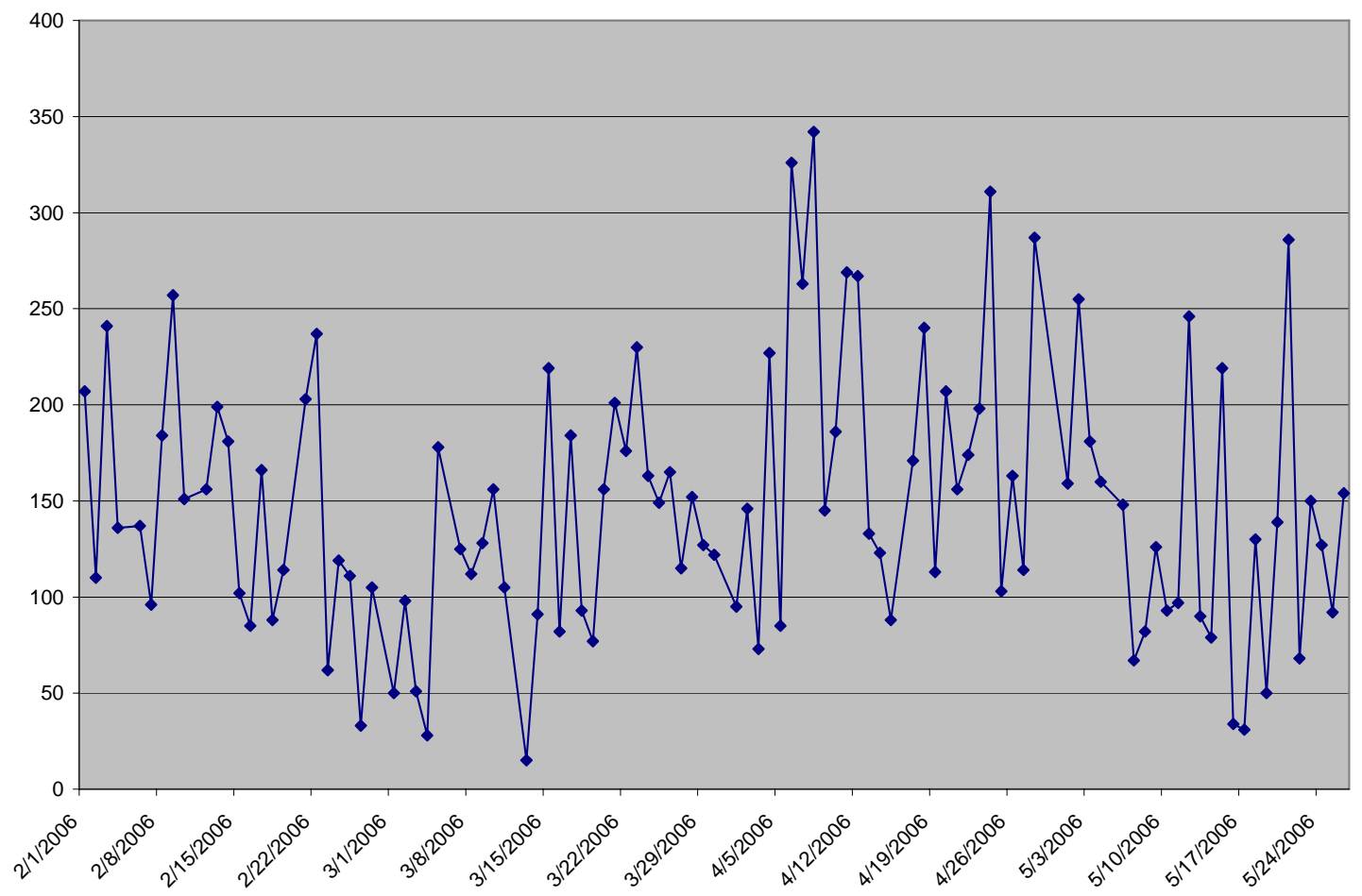

Why is there so much volatility in the number of arrests each day? Discussions with police officials suggest that a substantial but undetermined proportion of arrests are the result of police sweeps and stops. We were told that in one week some 40 percent of the stops yielded bookings or short-term arrests in police stations. We were unable to find out from the police whether this proportion is the norm, what crime-suppression effects it might have, and what happened next to those individuals who were apprehended.

It may be the case that the volatility in arrests is shaped by fluctuations in the number of police officers on patrol. This figure also is volatile as Figure Eleven below suggests, ranging from under 3,000 to 5,000 between February and May 2006. Police officials explained that the location of patrols and sweeps is shaped by reports of crime and their analysis, but the daily fluctuation in number of officers on patrol is shaped by other considerations, too, including elections, which took place in April. 


\section{Figure 11. Number of Police Officers on Active Patrol, Dominican Republic, February-May 2006}

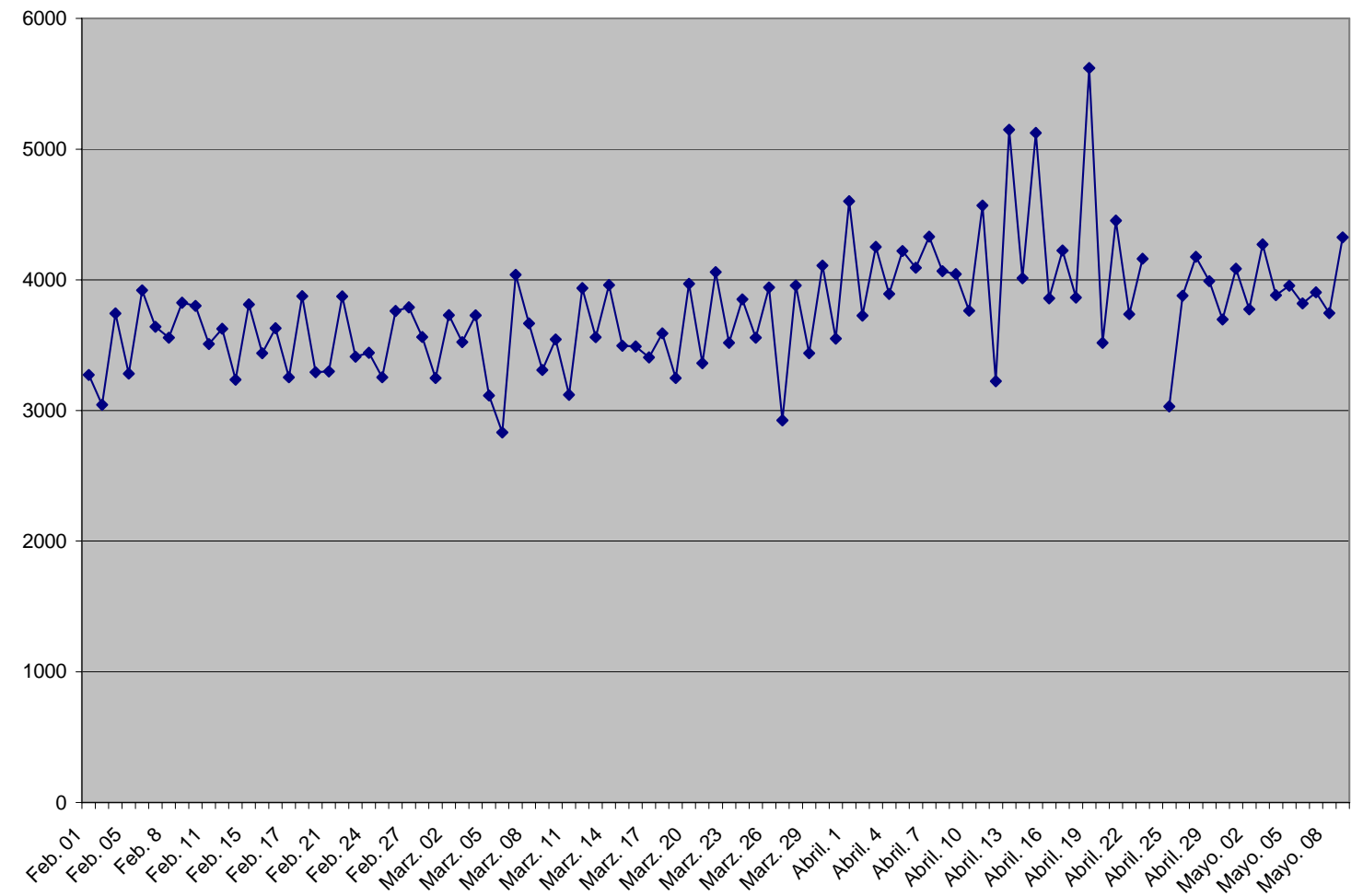

From other justice officials we learned that few of the approximately 50,000 to 55,000 annual arrests are pursued further by the justice system. According to data from the Ministerio Publico, judges granted 12,237 requests to continue an arrest in the twelve month period of September 2004 to August 2005. In 5,318 of these instances (43.4\%), a judge later ordered the suspect held in pretrial detention pending the outcome of trial. ${ }^{27}$ Beyond this, we can say very little as the government does not track the proportion of people arrested who were later held accountable for their behavior by the justice system.

The use of arrest powers by the police in the Dominican Republic, in short, is not typically followed by prosecution and even less likely to be followed by imprisonment. From a crime reduction perspective, this might be a good thing. If serious crime is reduced in areas where such stops are made, the police may be making an important contribution to public safety. Moreover, if the police are conducting stops within the law, and if the consequences for those stopped are brief and bearable, then the police may be using arrest powers in ways that reinforce the rule of law.

Here, however, we cannot say that stops are being used in this constructive way. Specifically, two features of the stops raise concerns. Only a small proportion of arrests are reviewed by prosecutors or scrutinized by courts, and the stops themselves are not

\footnotetext{
${ }^{27}$ The Supreme Court is in the process of installing a system by which to track the number of requests for arrest and detention that are granted by the judiciary. Personal Communication with Nestor Borroa, Department of Statistics, Supreme Court of the Dominican Republic.
} 
subject to independent oversight. A modern justice system that relies on stops and arrests for minor offenses to suppress crime without imposing substantial penalties still needs a means to assure that the police are acting within the law in their interactions with the public. Equally important, the impact of these stops and arrests on crime is uncertain, for the police do not yet analyze whether their stops are followed by a reduction of crime in the immediate vicinity of the police actions.

If one way to assess the strategic use of arrests is to examine their relationship to prosecution and judicial scrutiny, a second way is to measure the relationship between arrest and reported crime Fortunately a tentative analysis of this relationship is possible in Jamaica. In 2005, according to police data, there were 15,746 arrests in Jamaica. In the same year, there were 8,461 reported "major" crimes - murder, shooting, rape, carnal abuse, robbery, burglary, larceny. There were, in other words, nearly twice as many arrests as reported major crimes. Because most major crimes in any country are never "cleared" by an arrest, this ratio suggests that the Jamaican police are using arrest powers to deal with many "minor" offenses. ${ }^{28}$ As in the Dominican Republic, then, the key questions in Jamaica are (1) whether these are well-targeted to areas where major crimes are a problem, (2) whether the police are tracking whether the use of arrest for minor offenses leads to reductions in major crimes in those locations, and (3) whether the use of arrest against alleged minor offenders is subject to review by prosecutors, courts, or independent oversight agencies.

In Jamaica, there is reason to worry that the use of arrest powers is not strategically targeted on high crime areas. Why? The overwhelming majority of arrests in Jamaica took place in "rural" regions - that is, outside the metropolitan area where nearly half the population resides. The name "rural" may be misleading, since many rural areas have urban centers with populations over 100,000. Still, as the Figure Twelve below shows, 72 percent of all arrests took place outside the metropolitan area, while 57 percent of all major crimes were reported inside the metropolitan area.

Figure 12. The Distribution of Arrests in Jamaica, 2004-2005

\begin{tabular}{|cccccccccccc}
\hline & \multicolumn{4}{c}{ Arrests, Corporate Area } & \multicolumn{4}{c}{ Arrests, Rural Area } \\
\hline \hline Year & C.I.B. & Reg & Spec & D.C. & SubTotal & C.I.B. & Reg & Spec & D.C. & SubTotal & Grand Total \\
$\mathbf{2 0 0 5}$ & 2580 & 1615 & 137 & 111 & $\mathbf{4 4 4 3}$ & 4697 & 5697 & 280 & 629 & $\mathbf{1 1 3 0 3}$ \\
$\mathbf{2 0 0 4}$ & 3225 & 2024 & 103 & 166 & $\mathbf{5 5 1 8}$ & 5170 & 5179 & $\mathbf{2 4 6}$ & $\mathbf{1 5 7 4 6}$ & $\mathbf{1 1 2 6 8}$ & $\mathbf{1 6 7 8 6}$ \\
\hline
\end{tabular}

Key: "C.I.B" refers to the Criminal Investigative Branch; "Reg" denotes constables or patrol officers; "Spec" refers to an auxiliary branch of the JCF; and "D.C" denotes district constables.

\footnotetext{
${ }^{28}$ For example, state and local police departments in the United States in 2004 cleared 62.6 percent of murder offenses, 55.6 percent of aggravated assaults, 41.8 percent of forcible rapes, and 26.2 percent of robbery offenses. The data for major property crimes showed that agencies cleared 18.3 percent of larcenytheft offenses, 13.0 percent of motor vehicle theft offenses, and 12.9 percent of burglary offenses.
} 
Arrests in Jamaica, in other words, are not closely aligned with patterns of offending as measured by the distribution of reported major crime. ${ }^{29}$ The high proportion of arrests in "rural" areas may have other strategic purposes, be shaped by the distribution and patrol of officers, or even the requests of community leaders and the likelihood of reporting offenses, but such information is not routinely reported or correlated in the analysis of arrest patterns.

A third way to measure the strategic use of arrest powers is to examine the relationship of arrests to imprisonment. Here, we can make this calculation in both Jamaica and the Dominican Republic. In Jamaica in 2005, the average daily prison population was reported as 3,982, approximately one-fourth of the number of annual arrests. In the Dominican Republic that year, the prison population was 12,858 , or roughly the same ratio to arrests as in Jamaica. Again, these ratios suggest that arrests are being used to manage crime in many cases wholly apart from penal sanctions. And again, this use of arrest powers to manage crime directly, rather than merely to take an offender the first step on the way to prison, is increasingly considered a sign of good police strategy if it is targeted, measured for its effect on crime, and reviewed by an independent authority. ${ }^{30}$

The point here is not that there is some abstract, ideal distribution of arrests. Rather, arrests represent an expensive and intrusive use of police power that can be used carefully and deliberately to achieve crime reduction goals. Early experience in other countries suggests that this usually involves a balance of arrests for major offenses with selective use of arrests for minor offenses that are related, in that particular place, to serious crime and violence. Moreover, arrest powers must be used in a manner that does not undermine the legitimacy and public support of law enforcement.

\section{International Comparisons}

This last ratio of arrests-to-prisoners can be used to compare, at a very rough level, the use of arrest in Jamaica and the Dominican Republic with the use of arrest in other countries. In the United States and South Africa, for example, where the number of arrests per capita is unusually high and — at least in the case of the US - not strongly influenced by the number of serious crimes, most arrests are neither removing serious criminals from society nor strategically targeted for the reduction of major crime. Instead, it appears that they principally serve as a means of maintaining order and the authority of the police. $^{31}$ There are important exceptions to that generalization. For example, the use of arrest for minor offenses in New York City is frequently cited as the model of strategically targeted arrest for crime reduction purposes. Such local variation is lost in the national statistic. Even in New York City, however, these arrests for minor offenses,

\footnotetext{
${ }^{29}$ The data on recorded crimes and police arrests come from the Department of Statistics of the Jamaican Constabulary Force, which generously shared information and insights about crime analysis and problem identification.

${ }^{30}$ See: Weisburd and Braga.

31 The number of arrests in the US declined by 3.9\% between 1990 and 2004, while there was a 24.8\% reduction in reported violent crimes. See Uniform Crime Reports, www.ojp.usdoj.gov/bjs
} 
are rarely reviewed by prosecutors or courts. The only independent check on the legality of these arrests is New York City’s Civilian Complaint Review Board.

In Russia, by contrast, arrest is used surprisingly sparingly, and almost exclusively for the purpose of bringing offenders accused of major crimes before the courts. In 2005, when well over a million serious crimes were reported, there were 297,556 arrests. Nearly 70 percent all of those people arrested were later detained, virtually all of these individuals were tried and convicted, and two-thirds remained in prison for their sentence. This is reflected in a very low arrest rate and a ratio of arrests-to-prisoners of less than one-toone.

Jamaica and the Dominican Republic fall between the two extreme examples of the United States on the high end, and Russia on the low end in terms of the volume of arrest. As the table below shows, in Jamaica and the Dominican Republic, the ratio of arrests-toprisoners is 4:1 and generally in line with ratios in Colombia and Chile.

The rates of arrest and imprisonment shown in the table illustrate how heavily each country uses these coercive powers, but the ratio tells us something additional: the balance between the use of arrest and the use of imprisonment in the control of crime.

Figure 13. Arrests and Imprisonment for Selected Countries, 2005

\begin{tabular}{r|rrrrr} 
& \multicolumn{1}{|c}{ Arrests $^{1}$} & Prisoners $^{2}$ & $\begin{array}{c}\text { Arrest Rate } \\
\text { (per 1K) }\end{array}$ & $\begin{array}{c}\text { Imprisonment } \\
\text { Rate (per 100k) }\end{array}$ & $\begin{array}{c}\text { Arrest:Prisoner } \\
\text { Ratio }\end{array}$ \\
\hline United States & $13,639,500$ & $2,186,230$ & 46.0 & 737 & $6: 1$ \\
\hline Colombia & 342,863 & 63,110 & 7.9 & 145 & $5: 1$ \\
\hline $\begin{array}{r}\text { Dominican } \\
\text { Republic }\end{array}$ & $\mathbf{5 5 , 0 0 0}$ & $\mathbf{1 2 , 8 5 8}$ & $\mathbf{6 . 0}$ & $\mathbf{1 4 0}$ & $\mathbf{4 : 1}$ \\
\hline Jamaica & $\mathbf{1 5 , 7 4 6}$ & $\mathbf{3 , 9 2 8}$ & $\mathbf{5 . 7}$ & $\mathbf{1 4 2}$ & $\mathbf{4 : 1}$ \\
\hline Chile & 118,521 & 37,000 & 7.3 & 229 & $3: 1$ \\
\hline Russia & 297,500 & 823,451 & 2.1 & 576 & $0.4: 1$
\end{tabular}

${ }^{1}$ Arrest figures for the United States are for 2004. Figures for Dominican Republic are estimates.

${ }^{2}$ Includes sentenced and awaiting trial prisoners, including prisoners held in police stations for countries other than the United States

3 Population estimates are taken from The World Fact Book, https://www.cia.gov/cia/publications/factbook/index.html and are for July 2006, except for the United States, where the figure is the US Bureau of the Census estimate for June 30, 2005. 


\section{Prosecuting and Adjudicating Cases: Focusing on Bellwether Crimes}

The only crime for which there is high confidence in the data in both the Dominican Republic and Jamaica is homicide. This is one reason why international comparisons of crime rates focus on homicide. It also means that tracking the response to homicide can provide a partial but relatively accurate glimpse into the work of police, prosecutors, and courts. But homicide is an exceptional crime, even in countries with a lot of it. An important question, therefore, is whether homicide serves, in fact, as a bellwether crime, with changes in homicides leading to changes in other serious, and more numerous, violent offenses.

The answer to the bellwether question will tell us whether or not a focus on prosecuting homicide cases can serve as a wider public safety strategy. These prosecutions are important in their own right, but do the resources devoted here help reduce violence more generally? Do efforts to curb the growth of murders lead to parallel reductions in other offenses?

The evidence from around the world on this point is mixed. In the United States, the dramatic decline in per capita rates of homicide in the 1990s was accompanied by, and some criminologists believe triggered by, a reduction in armed robbery. In South Africa, by contrast, where per capita levels of murder fell from 67 to 43 between 1994 and 2004, the incidence of robbery (a far more frequent crime) increased by 32 percent. The decline in homicide in that country, in other words, has not served to leverage reductions across the board in crime and violence. ${ }^{32}$ In Colombia, the dramatic decline in homicide in the last three years has not coincided with a similar decline in other major offenses. Commercial and Individual Theft, for example, increased substantially in the past three years.

\section{Is homicide a bellwether in Jamaica and the Dominican Republic?}

In both countries, there have been alarming increases in the number of murders in recent years. As the Figure 14 shows, in Jamaica, the number of homicides nearly doubled between 2003 and 2005, from 975 to 1674. In the Dominican Republic, the number of homicides began to grow earlier and more than doubled from 1,065 in 2001 to 2,403 in 2005. More recently, as the chart below shows, the number of homicides has begun to fall in both countries. If the trends for the past six months continue, both countries will record dramatic reductions in the total number of murders in $2006 .^{33}$

\footnotetext{
32 See Antony Altbeker, "Murder and Robbery in South Africa: A Tale of Two Trends,” draft paper, 2006.

33 The data on homicides in this report come from the Jamaican Constabulary Force and Procuraduria General de la Republica. Because these figures may diverge slightly from those reported by other sources (such as the Panamerican Health Organization) or published by international organizations such as the United Nations Office on Drugs and Crime, we use them primarily to depict trends.
} 
Figure 14. Homicide Trends, Jamaica and the Dominican Republic, 19962006

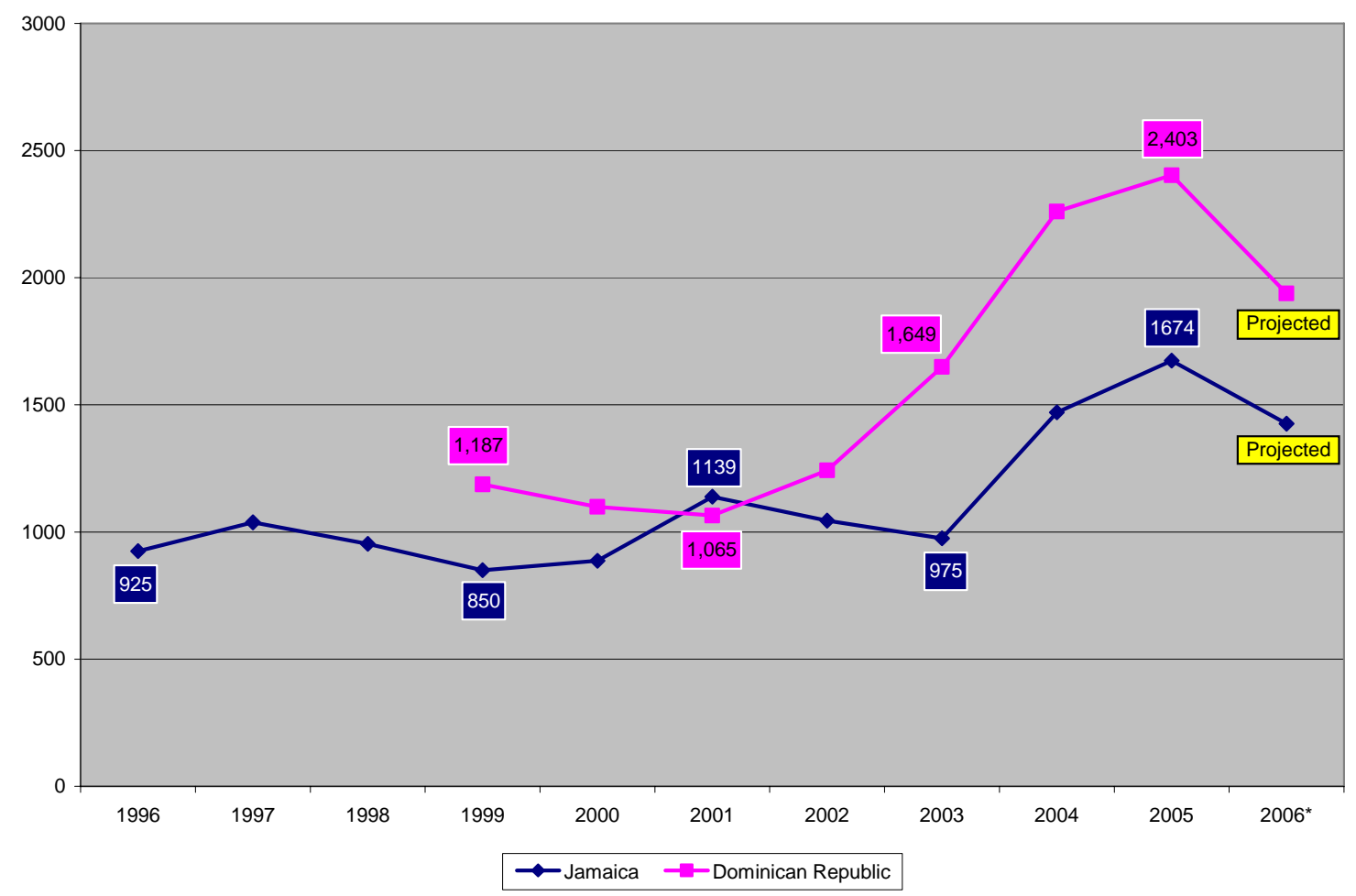

There is great interest in understanding the sources of this reduction in both countries, irrespective of its contribution to wider public safety. Murder is an important issue in its own right. In Jamaica there is a tendency to credit the police's "Murder Reduction Plan” for the recent reduction. While we cannot assess that claim with these data alone, the chart below shows that the number of homicides was declining in most months of 2005 until it spiked and the declined again in December, when the JCF introduced the murder reduction plan. Thereafter, Jamaicans experienced the most sustained decline in homicide in this period. 
Figure 15. Homicide Trends in Jamaica and the Dominican Republic, 20052006.

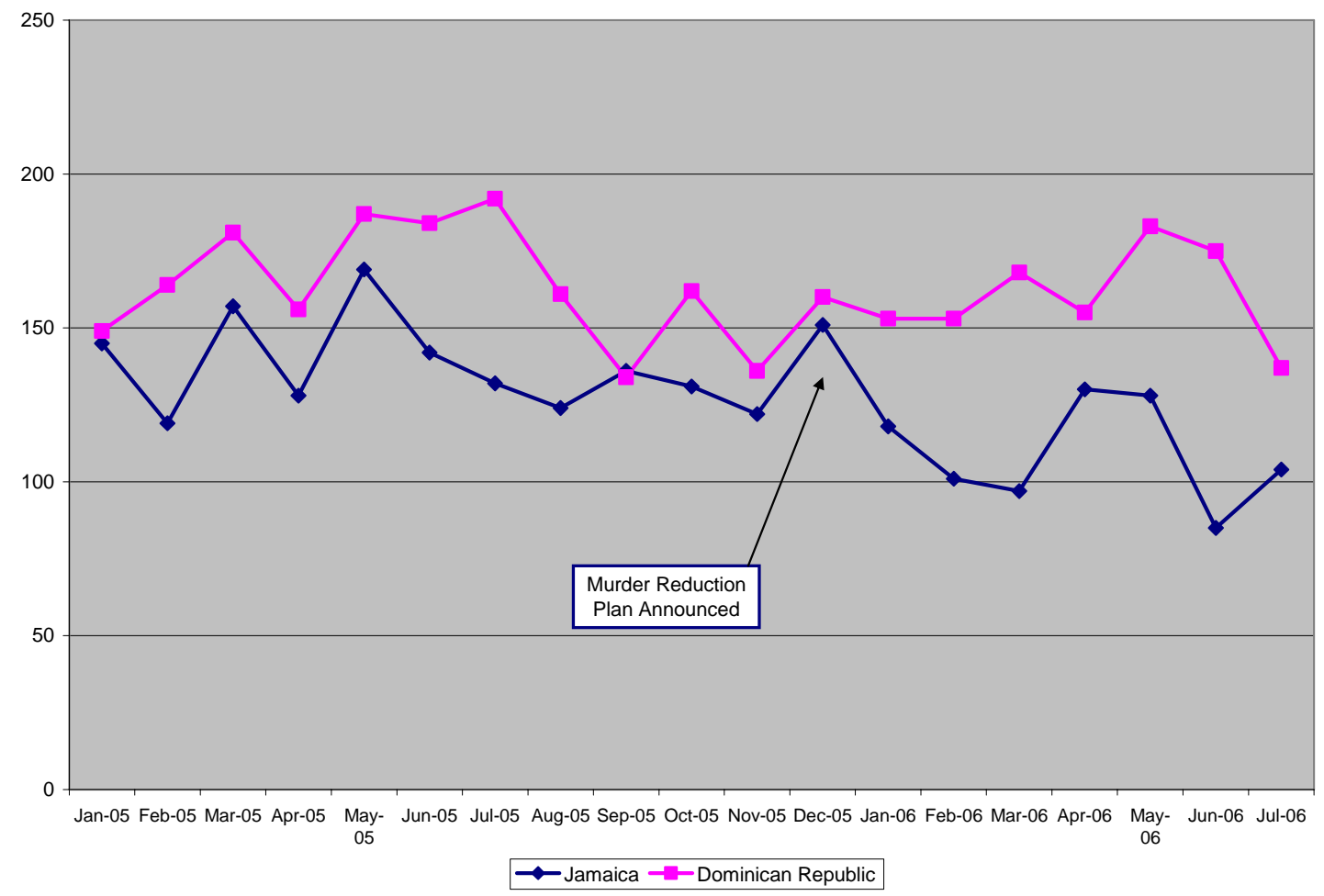

The reduction in homicide in both countries is welcome, but it will be more welcome if efforts to reduce homicide have positive side-effects on other types of offending. As far as we know, neither government has yet examined this question, although it is possible to approximate this analysis for Jamaica with some of the existing data. ${ }^{34}$

The chart below records trends over the past six years for five of what the Jamaican Constabulary Force calls "major crimes" - Murder, Shooting, Rape, Robbery, and Breaking. We omit figures for Carnal Abuse and Larceny, which are both much lower and less reliable. The graph suggests that homicide may no longer be a bellwether for the more numerous robberies in Jamaica. Reported robberies are clearly not affected by the most recent reduction in homicide. Furthermore, the persistence of robberies in the face of reductions in murder is probably not distorted by increased reporting of robberies, since an increase in reporting should logically have affected shootings as well as robberies.

\footnotetext{
${ }^{34}$ Since published government reports on crime in the Dominican Republic provide data only on violent deaths, we focus here only on Jamaica.
} 
Figure 15. Major Reported Crimes in Jamaica, 2000-2006.

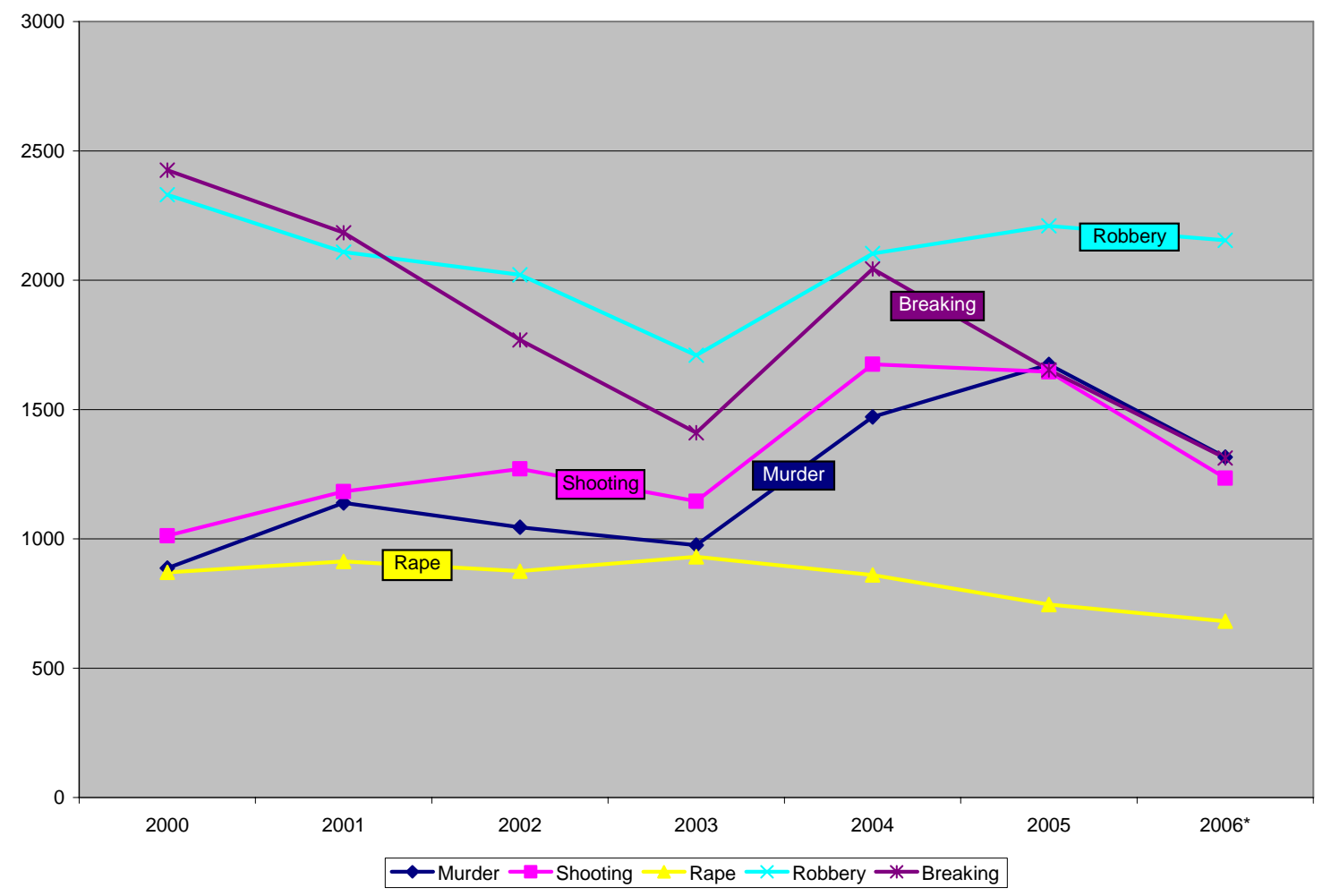

The graph does suggest, however, that there might be a relationship between reductions in homicide and some other gains in public safety, since the number of reported breakings and shootings follows the trajectory of homicide for the past few years. There is, to repeat, very little confidence in the accuracy of these data other than for homicide, even within the police force. Still, the government could conduct a more nuanced and reliable analysis of the relationship of homicide to shootings, robbery, and breaking, perhaps for a specific parish where the confidence of the public in the police is growing and thus the quality of reported data better.

Answering the bellwether question more reliably could make the Jamaican focus on homicide a more powerful asset for public safety generally than it already is. In the meantime, prosecutors and their colleagues throughout the justice system would be well advised to focus separately on the problem of robberies, the trend for which appears to have become detached from that of homicide.

\section{Building Confidence in Justice: Focusing on the Poor and Marginalized Groups}

The governments of both Jamaica and the Dominican Republic today seek to build public trust in the justice system. They recognize that where the public distrusts the police and justice system, witnesses and victims will not solicit their help, assist in investigations, and may take matters into their own hands. But levels of public confidence in the justice system in both Jamaica and the Dominican Republic have not yet been measured or cultivated with great care. We know more about attitudes toward the police than toward 
the system as a whole, and what researchers know about perceptions of the police is not sufficient to help the government build more of it. ${ }^{35}$ Still, the research available creates the foundation for a better understanding of public desires for safety and justice and also how the government can respond to it. How, then, with information already available, can these governments build convert confidence into greater legitimacy and respect for the system as a whole?

Repeated surveys of representative samples of the population are expensive but common ways of measuring confidence in the justice system over time, with the same survey often asking both about opinions and experiences. These two kinds of survey questions measure very different things: one measures beliefs about crime and the work of the justice system; the other examines experiences of crime and contact with the system. Used together, answers to these questions can help governments know whether experiences of crime and contact with the justice system shape confidence in the system, and if so, what kinds of experiences of crime and contact matter most. Armed with this kind of information, governments can then shape the priorities of law enforcement and also adjust their routines in order to strengthen public confidence. Governments can also use this knowledge to modify the way they work with independent forces such as the media to improve public understanding of the justice system and increase civic trust. Finally, these surveys can be disaggregated by income, gender, or other characteristics of victims that can help governments focus on the confidence that vulnerable groups are feeling in the justice system.

In both Jamaica and the Dominican Republic, data on perceptions and victimization so far have not been used by governments to increase public confidence in justice. Instead, researchers have used this information primarily as a better measure of the extent of crime and of the reasons people do not report crime. We know from census-based questions on victimization in Jamaica that probably only one-in-six robberies is reported to the police. ${ }^{36}$ In the Dominican Republic, it appears only one-in-eight robberies is reported.

We also know that people in the Dominican Republic who do not report crimes are more likely to believe the police will choose not to help than to believe the police are incapable of helping. For example, as the table in Figure 7 shows, nearly 42 percent of people who did not report the theft of parts of their vehicle or the contents of their car believed the police "will not do anything," while less than 10 percent thought the police "are incapable of doing anything."

\footnotetext{
${ }^{35}$ For example, Anthony Harriott reports that the public "lost confidence" in the police in the 1990s. With additional evidence about the levels, character, or sources of the confidence the public apparently had before then, we can diagnose the reasons for the loss of this confidence - eg whether it was related to ineffectiveness, disrespect, police violence, or other factors. See Anthony Harriott, Police and Crime Control in Jamaica: Problems of Reforming Ex-Colonial Constabularies, Kingston, University of West Indies Press, 2000, p. 125.

${ }^{36}$ See "Crime and Violence in Jamaica," in the World Bank report on crime and violence in the Caribbean (forthcoming).
} 


\section{Reasons for Not Reporting a Crime \\ Attributable to Perceptions of the Police}

(percent of all crimes not reported)

\begin{tabular}{|c|c|c|c|c|c|}
\hline Type of Offense & $\begin{array}{c}\% \\
\text { victimizations } \\
\text { reported }\end{array}$ & $\begin{array}{l}\text { "The Police } \\
\text { Will Not Do } \\
\text { Anything" }\end{array}$ & $\begin{array}{l}\text { Reasons for } \\
\text { "The Police } \\
\text { Are Incapable } \\
\text { of Doing } \\
\text { Anything" } \\
\end{array}$ & $\begin{array}{l}\text { ot Reportir } \\
\text { The Police } \\
\text { Might be } \\
\text { Involved }\end{array}$ & $\begin{array}{c}\text { The Police } \\
\text { Might Request } \\
\text { a Bribe }\end{array}$ \\
\hline Autotheft & 74.1 & 34.6 & 12.5 & 7.6 & $\mathrm{n} / \mathrm{a}$ \\
\hline Robbery of Auto Parts or Contents & 27.8 & 41.7 & 9.8 & 8.2 & 4.4 \\
\hline Vandalism of Autos & 19.3 & 24.9 & 9.9 & 3.6 & $\mathrm{n} / \mathrm{a}$ \\
\hline Attempted Burglary & 21 & 24.9 & 8.8 & 3 & 1.2 \\
\hline Breaking and Entering & 29.6 & 26.4 & 7.9 & 2.3 & 1.3 \\
\hline Assault & 26.2 & 34.4 & 11.5 & 5.4 & 1.6 \\
\hline Theft & 12.1 & 22.5 & 7.4 & 1 & 1.3 \\
\hline
\end{tabular}

Source: “Principales Hallazgos de la Encuesta Nacional de Hogares, Enhogar 2005,” Oficina Nacional de Estadistica, Republica Dominicana.

Is it easier for government to increase the perception of willingness than the perception of ability within the police? That probably depends on whether perceptions are accurate. It also is not clear what the government would do if the public began to report more crimes. $^{37}$ Yet the data, combined with information about the actual outcome of police responses to these specific crimes, could be used to bolster confidence in the police and in the justice system.

Notice, for example, that low confidence in the police apparently has little to do with perceptions of corruption, since only a tiny fraction of respondents believe a bribe will be requested, and a small portion thinks the police might be involved in the crime. Also, perceptions of police competence, which governments often try to improve through additional resources, seem unrelated to the likelihood of reporting. Not many people believe the police are incapable. Many people, however, believe the police lack a willingness to do something.

We know less about the experiences of those who do report crime than those who do not, but it appears that satisfaction with the response of the justice system in the Dominican Republic does not depend on the effectiveness of police, the extent of damage experienced, or the quantity of goods returned. Data from the same survey indicate that victims of minor theft (robo al descuido) had the highest rate of satisfaction (57\%), but were not more likely than others to have their property recovered or the offender arrested. According to the Division of Criminal Investigations (DICRIM), only 32 percent of the crimes of theft were "cleared." By contrast, 84 percent of automobiles stolen in the DR between August 2005 and January 2006 were recovered, and yet only 30 percent of these victims were satisfied.

\footnotetext{
${ }^{37}$ The premise of much research on victimization in the Caribbean seems to be that a low level of reporting of crime is itself dangerous for public safety, and that higher levels of reporting would positively affect government behavior and also improve social well-being. But we don't know if that is true.
} 
Should the government of the Dominican Republic then focus its efforts on improving the timeliness of the response to complaints of crime and also the character of assistance offered? Would a retail approach to improving consumer "satisfaction" with police services beget public confidence and/or greater legitimacy in the justice system? As with efforts to reduce homicide, government efforts to improve confidence in the justice system are more likely to succeed when they are focused on specific locales and specific needs. A one-time survey of public opinion designed to support the installation of community policing in Santo Domingo, found generally negative perceptions of the police, but these results varied considerably by neighborhood. In one neighborhood in the capital, 61 percent of respondents rated the work of the police in response to crime as "average," "good,” or "very good," whereas in another neighborhood 67 percent said it was "bad” or "very bad.",38

By comparing these data with information about the frequencies of victimization, rates of reporting of crime, and patterns of patrol in neighborhoods with poor judgments of the police, the government would know what types of adjustments could improve confidence in the justice system. And by repeating the surveys over time, the government could reward those officers and departments that make the greatest progress. But it may be possible to gauge and improve confidence in the justice system without additional victimization surveys and public perceptions data. Below, we propose two proxy measures of confidence and suggest how data about crime might be converted into indicators that help governments measure and build more public confidence.

\section{Proxy Measures of Confidence: Data on Reported Crimes}

Variation in the proportion of reported assaults that cause grievous bodily harm in relation to reports of common (i.e. less serious) assault may hold clues about changing levels of public confidence in the justice system. In countries with high confidence in the police, one might expect the public to report far more common assaults than serious assaults. Where citizens believe the justice system can help them and should know about and intervene in cases of physical violence, the police will become aware of most assaults. By contrast, in countries or cities with low confidence in the justice system, one might expect citizens only to report those assaults for which some state intervention, and possibly medical attention, cannot be avoided.

In South Africa, where we know confidence in the police is fairly low, the ratio of reports of common assault to those of serious assaults is 1.1:1, and it has risen only slightly since 1995, when it was 0.9:1. In Russia, where general rates of confidence in the police are also low, this ratio is $1: 1$. The reporting of assault in Jamaica follows roughly the same pattern. As the data in the table below show, the ratio of grave to minor reports of assault is nearly 1:1. In Chile, in contrast, where confidence in the police is understood to be higher, the ratio of common assault to serious assault is close to $4: 1$.

\footnotetext{
${ }^{38}$ Plan Nacional de Seguridad Democratica, July 2005.
} 


\begin{tabular}{|c|c|c|c|}
\hline \multicolumn{4}{|c|}{ Reports of Grave and Minor Assault, Jamaica, 2005} \\
\hline & Type of Assault & $\mathrm{n}$ & $\%$ \\
\hline \multirow{5}{*}{ Minor } & Indecent & 258 & $3.2 \%$ \\
\hline & Common Law & 582 & $7.3 \%$ \\
\hline & Occasioning Bodily Harm & 2719 & $33.9 \%$ \\
\hline & Occasioning Grave Bodily Harm & 219 & $2.7 \%$ \\
\hline & Other & 210 & $2.6 \%$ \\
\hline & subtotal & 3988 & $49.7 \%$ \\
\hline \multirow{5}{*}{ Grave } & Attempted Murder & 24 & $0.3 \%$ \\
\hline & Felonious Wounding & 157 & $2.0 \%$ \\
\hline & Intentional Wounding & 847 & $10.6 \%$ \\
\hline & Unlawful Wounding & 3008 & $37.5 \%$ \\
\hline & subtotal & 4036 & $50.4 \%$ \\
\hline
\end{tabular}

Source: Department of Statistics, Jamaican Constabulary Force

Changes in the relative rates of reporting of these incidents might complement information about victimization, which should be monitored, and also alert the government to changes in the willingness of citizens to invoke the state in responding to violence. In both countries, the governments routinely collect this type of information and could today begin to track improvements or deteriorations in public confidence, especially in vulnerable and poor neighborhoods, through the measurement of changes within the structure of reported assaults.

\section{Incarcerating Prisoners: Reducing Recidivism}

As we have already seen, the Jamaican Department of Correctional Services is beginning to measure recidivism, but it is limited in what it can count. An indicator that measures the percent of admitted prisoners with a prior period of incarceration is too ambiguous to be useful. A better measure, and one more widely used globally, is the percentage of prisoners released in a particular year who are re-admitted within three or five years. This indicator is also ambiguous - responsive to enforcement efforts as well as changes in actual criminal conduct by released prisoners - but it is better than the alternatives. Moreover, it could be calculated by the Department on its own, once it puts in place record systems that accurately identify new persons admitted with their prior records.

Even better, however, would be systems that track the re-arrest of released prisoners, or surveys that capture the experiences of released prisoners in much shorter time periods. Such data, focusing on recidivism in the first month, quarter, and year after release, would allow officials and prevention programs to identify some of the proximate causes of re-offending. 


\section{Conclusion: Governance and the Direction of Criminal Justice Reforms}

Reducing crime and violence through the operation of the criminal justice system turns out to be difficult work. We have seen, in part one of this report, how the governments of Jamaica and the Dominican Republic are managing this work today, with each institution in the system pursuing its own tasks. In part two, we examined several recent developments and future prospects for aligning these efforts more closely and focusing more directly on the reduction of crime. Now, in this final part, we turn to the governance challenges that face any nation seeking to achieve such an improvement in the effectiveness of its criminal justice system. Governments need strong instruments to bring together the disparate threads of innovation, adjustment, and discovery that take place on a daily basis in justice agencies. They also need inter-agency governance mechanisms and incentives to help individual agencies align their work with system-wide goals.

If sector-wide governance mechanisms are to succeed, their authority must go beyond performance measurement. Where documentation and monitoring are the only functions of national coordinating commissions, the alignment of the work of disparate institutions of justice will be weak. ${ }^{39}$ With strong instruments of management in the justice sector, however, governments can prevent good policies from being overtaken by bad practices and manage public demands for arbitrary or uncoordinated action against crime.

The recent history of justice reforms in both Jamaica and the Dominican Republic illustrates the need for such interagency mechanisms. Until quite recently in both countries, reforms in the justice sector have focused almost exclusively on the police, which, as we have seen here, cannot bear all the responsibility for reducing crime and violence. Moreover, responsibility for implementing promising public safety programs and, in the Dominican Republic, the ambitious justice sector reforms of 2004, has fallen primarily to the institutions whose work they sought to transform. By leaving justice and public safety in the hands of separate and often competing institutions, governments tread a circuitous path to the reduction of crime and violence.

The difficulties are evident in the slow pace of police reform. The Jamaican Constabulary Force, for example, has experienced a series of modernization programs informed by decades of foreign advice. Ambitious recommendations, such as those advanced by the Wolfe Commission in 1993, have sought to bring the JCF up to professional standards, while pilot projects supported with foreign assistance have attempted to introduce concepts such as community policing and intelligence-led policing. Nevertheless, most experts agree that the JCF today differs little from the police force in place at the onset of Independence: with a few exceptions, it remains a top-heavy, reactive police

\footnotetext{
${ }^{39}$ An example of sector-wide coordination currently limited to performance measurement is the role played by National Commission for the Coordination of the Reforms in Chile. For a discussion of these challenges, see Measuring Progress Toward Safety and Justice: A Global Guide to the Design of Performance Indicators Across the Justice Sector, Vera Institute of Justice, 2004. www.vera.org/indicators
} 
organization that does not serve community needs effectively, efficiently, or fairly. ${ }^{40}$ The force today also remains poorly trained and equipped, and vulnerable to corruption, frequently displaying excessive force in the least safe communities.

Despite these difficulties, efforts at reform continue. Important if modest innovations are underway today both at the top of the police and at the level of community policing. The JCF, for example, has introduced a Professional Standards Branch, which in addition to improving recruitment and training, is designing new performance evaluation instruments and might also acquire responsibility for internal affairs and investigations. In concert with the Ministry of National Security, the JCF is helping to introduce new public service programs in vulnerable communities, including parenting programs and community breakfasts for schoolchildren. ${ }^{41}$ These and other changes are taking place at the same time that the JCF acquires new conventional police technology, including cars and computers as well as better forensic and ballistic information systems. The question arises, therefore, whether there is a better structure available than has been established in the past to catalyze these modest reforms into a more thorough modernization of the JCF.

In the Dominican Republic, too, at least until the introduction of the new code of criminal procedure in October 2004, reforms of the justice system have concentrated on the modernization of policing. This strategy may have made sense initially, since the police were until recently, as the chief of the national police told us, "designed to serve a dictatorship." And yet the daily operations of the police as well as its public reputation and role began to be changed in earnest only in 2000, when a National Commission for the Reform and Modernization of the Police, which involved representatives from outside the police, began its work and articulated a new vision and mission for the police. Still, changes in the leadership of the police and executive halted the process of converting the vision into action.

Later, under a new government and with the adoption of a National Plan for Democratic Security in April 2005, the police acquired new goals directly related to improvements in public safety and equitable justice. The National Plan (hereafter, NPDS) calls for professionalization and modernization of the police in all aspects of its work, from training in human rights, to improved operations of forensic institutions, a more powerful Department of Internal Affairs, and different patterns of patrol in neighborhoods with high rates of crime and low levels of confidence in the police. The Plan also gives concrete meaning to "community policing" through pilot projects for "safe neighborhoods" (barrios seguros) in the capital, Santo Domingo, and its second city, Santiago. Closely linked to these efforts is an ambitious project for community prosecution, which emphasizes restorative justice and reduces the burden on law enforcement and other formal institutions of justice.

\footnotetext{
${ }^{40}$ See, for example, the assessments in Anthony Harriott, $\underline{\text { Police and Crime Control in Jamaica: Problems }}$ of Reforming Ex-Colonial Constabularies, UWI Press, Kingston, 2000, esp. 124, and the conclusions of a report by the Police Executive Research Forum, reported at www.jamaicagleaner.com/gleaner/feature/perf/page4.html

${ }^{41}$ Interview with Simeon Robinson, director Citizen Safety and Security Program, Ministry of National Security, Kingston, July 18, 2006.
} 
Today, the governments of Jamaica and the Dominican Republic are both poised to introduce better instruments of interagency governance, tying this history of police modernization to wider reform across the justice sector. In December 2005 and again in May 2006, the Ministry of National Security of Jamaica disseminated for public comment a green paper on public safety, in which it proposed, among other things, to locate responsibility for the implementation of such a strategy in the office of the Prime Minister. $^{42}$ In July 2006, the President of the Dominican Republic decreed the establishment of a National Security Council, whose job is to "plan, produce, coordinate, and evaluate the use of inter-institutional information for the prevention of crime." 43

The plans for the Security Council in the Dominican Republic are more advanced than in Jamaica, and yet its success is not assured. In order to succeed, the new National Security Council will need a staff and other resources that make it a real instrument of governance, as well as a composition that does not simply represent the leadership of individual agencies or repeat membership on other inter-governmental committees. It will also need special skills to master the tools, information, and indicators available to ensure the alignment of justice and coordinated efforts to prevent crime. And it will need a set of priorities that stretch beyond present concerns with public safety.

A robust Security Council in the Dominican Republic would be well positioned to drive forward the nascent operational innovations already described here. For example, such a Council could improve the strategic use of arrests, helping to balance the use of arrests between major and minor offenses and ensuring proper review of arrest powers by prosecutors, the courts, and independent oversight bodies. Such a Council might also establish a reliable baseline for future performance evaluation by organizing the information about justice already at its disposal and developing discriminating measures for cross-sector goals such as reducing violent crime and improving public confidence in the justice system in vulnerable communities. These and other tasks would augment its authority over the agencies whose actions it must coordinate. ${ }^{44}$

The vulnerability of visionary justice policies and long-term public safety plans to sudden swings in civic moods is well illustrated by the case of the Dominican Republic. At the end of July 2006, President Leonel Fernandez responded to public demonstrations for "peace and safety" with a series of pledges to introduce joint army and police patrols in specific neighborhoods, and to increase by 14,000 the number of police officers. It is not clear how this decree and the show of state force are consistent with prior plans for the modernization of the police force and the movement toward a problem-solving system of

\footnotetext{
${ }^{42}$ See the Green Paper prepared by the Ministry of National Security, "National Security Strategy for Jamaica: Toward a Secure and Prosperous Nation,” Revised May 2006, p. 99-100. On May 1, 2006, the non-government organization Jamaicans for Justice released a parallel strategy paper, "Road Map to A Safe and Secure Jamaica," whose preparation was supported by an opposition leader. See www.jamaicansforjustice.org

${ }^{43}$ For a report of the decree, see www.presidencia.gov.do/frontend/articulo.php?id=4225

${ }^{44}$ The government of Jamaica is not, at this writing, in a good position to establish a similar body, as it is still collecting comments on its Green Paper, and receiving international audits on and diagnostic studies of the justice sector.
} 
criminal justice. We hope that the new national security council will examine carefully how these new measures affect public safety and will report what it learns. ${ }^{45}$

Finally, in both Jamaica and the Dominican Republic, innovations in governance should widen the circle of functions within the criminal justice system. Victim services, indigent defense, addiction treatment, and other public health services might all be brought together in the service of reducing crime and violence. The governance of these interrelated functions cannot be effectively organized in a simple sequence along an assembly line or delegated to individual institutions. Rather, governance structures need to manage these together, recognizing that they form a complex web of inter-agency operations at every juncture of decision-making. Victims, for example, cannot be treated by hospitals, helped by social services, or protected by the prosecution and courts if the police do not embrace this goal and help complete these tasks. And without treatment, help, and protection, those victims and their neighbors will withhold their help in preventing future crime. Reducing crime through the arrest, prosecution, and punishment of offenders, in short, is only one aspect of the work of a criminal justice system that aims to deliver safety and justice.

\footnotetext{
${ }^{45}$ Initial press reports from emanating in the Presidency claim there has been a substantial reduction in levels of reported crime, especially in the so-called Safe Neighborhoods. To evaluate these claims, justice system researchers will have to investigate whether the reductions themselves are genuine, as then whether they can be attributed to the patrols. It is possible that even real reductions may be due to factors that preceded the patrols.
} 